\title{
Financial Advisors: A Case of Babysitters?*
}

\author{
Andreas Hackethal \\ Goethe University Frankfurt \\ Michael Haliassos \\ Goethe University Frankfurt, CFS, and CEPR \\ Tullio Jappelli \\ University of Naples Federico II, CSEF, and CEPR
}

July 6, 2009

\begin{abstract}
We merge administrative information from a large German discount brokerage firm with regional data to examine if financial advisors improve portfolio performance. Our data track accounts of 32,751 randomly selected individual customers over 66 months and allow direct comparison of performance across self-managed accounts and accounts run by, or in consultation with, independent financial advisors. In contrast to the picture painted by performance records, econometric analysis that corrects for the endogeneity of the choice of having a financial advisor suggests that advisors are associated with lower total and excess account returns, higher portfolio risk and probabilities of losses, and higher trading frequency and portfolio turnover relative to what account owners of given characteristics tend to achieve on their own. Regression analysis of who uses an IFA suggests that IFAs are matched with richer, older investors rather than with poorer, younger ones.
\end{abstract}

Keywords: Financial advice, portfolio choice, household finance.

JEL codes: G1, E2, D8.

*Acknowledgements: We are grateful to Jose Martinez, Pedro Mira, Steven Stern, John Rust, and participants in the November 2008 Fundación Ramón Areces conference on 'Population Ageing and its Economic Consequences' in Madrid, the 2009 SIFR-NETSPAR Pension workshop in Stockholm, the 2009 IMAEF conference in Ioannina, the 2009 CSEF-IGIER Symposium in Economics and Institutions in Capri, the SAVE Conference in Mannheim, and in the seminar series at the Universities of Exeter and Leicester for very helpful comments and suggestions. We would like to thank Ralph Bluethgen for outstanding research assistance. Haliassos acknowledges research funding from the German Research Foundation (Deutsche Forschungsgemeinschaft - DFG) under the project 'Regulating Retail Finance'. Jappelli acknowledges funding from the Italian Ministry of Universities and Research. 


\section{Introduction}

In recent years households have increased their exposure to financial risk taking, partly in response to the demographic transition and increased responsibility for retirement financing. Recent research points to differential financial literacy and sophistication across households, creating the potential for important distributional consequences of these developments (Campbell, 2006; Lusardi and Mitchell, 2007).

In principle, financial advisors could ameliorate consequences of differential ability to handle finances by improving returns and ensuring greater risk diversification among less sophisticated households. Indeed, delegation of portfolio decisions to advisors opens up economies of scale in portfolio management and information acquisition, because advisors can spread information acquisition costs among many investors. Such economies of scale, as well as possibly superior financial practices of advisors, create the potential for individual investors to improve portfolio performance by delegating financial decisions. But delegation entails costs in terms of commissions and fees, and might give rise to agency problems between advisors and firms and between advisors and customers, as shown by Inderst and Ottaviani (forthcoming). These arise mainly because of conflicting incentives for financial advisors: on the one hand they need to sell financial products and on the other they need to advise customers on what is best for them to do, one of many conflicts of interest in financial markets. Stulz and Mehran (2007) reviews the existing empirical literature on the nature and implications of these conflicts mainly focusing on analysts.

Underlying much of the existing literature on financial literacy, the possible role of financial advice and the case for regulation of financial advisors is the notion that financial advisors tend to be used by less informed or sophisticated investors who could be easily misled by them. Regulation and/or incentives are then needed to make sure that advisors contribute their expertise to these inexperienced investors. In this paper, we examine three questions. First, we ask how brokerage accounts run by individuals without financial advisors actually perform compared to accounts run by (or in consultation with) financial advisors. Second, whether financial advisors tend to be matched with poorer, uninformed investors or with richer, experienced but presumably 
busy investors. Third, whether the contribution of financial advisors to the accounts they do run is actually positive relative to what investors with the characteristics of their clients tend to obtain on their own. Such direct comparisons are made possible by an unique administrative data set from a large German discount brokerage firm that allows its clients choice of whether to run their accounts themselves or with the guidance of an independent financial advisor (IFA). The answers we obtain provide quite a different perspective on financial advice.

Our data track accounts of 32,751 randomly selected individual customers over 66 months. Performance records, likely to shape perceptions of the public, paint a very positive picture: financial advisors accounts offer on average greater returns, both in total and relative to the security market line; lower risk, systematic and unsystematic; lower probabilities of losses and of substantial losses; and greater diversification through investments in mutual funds. In econometric analysis that controls for client demographics and experience and for possible endogeneity of the use of a financial advisors, the latter are seen to lower total and excess returns, raise portfolio risk (systematic and unsystematic), increase the probabilities of losses and of substantial losses, and increase trading frequency and portfolio turnover relative to what account owners of given characteristics tend to achieve on their own. Regression analysis of who delegates portfolio decisions suggests that advisors are matched with richer, older investors rather than with poorer, younger ones. In this respect, they are similar to babysitters: they are matched with well-to-do households, they perform a service that parents themselves could do better, they charge for it, but observed child achievement is often better than what people without babysitters obtain, because other contributing factors are favorable.

The paper is organized as follows. In Section 2 we discuss the role of financial advice in overcoming investors' informational constraints and their incentives in handling financial portfolios in view of relevant existing literature. Section 3 describes the data and the measures that we use to characterize portfolio performance. Section 4 compares records of account performance with and without involvement of financial advisors which might help shape public perceptions about the usefulness of IFAs. Section 5 studies econometrically the role of investor characteristics and regional factors in determining which investors are matched with financial advisors. Sections 6 and 7 report regression estimates of the effects of financial advisors on 
account performance, return volatility, trading, turnover, and diversification. Section 8 summarizes our main findings.

\section{The Role of Financial Advice}

There is a limited but budding theoretical literature on the possible role of financial advisors. Current theoretical work but also policy debate on financial regulation seem to be based on the idea that financial advisors know what is good for individual customers but have an incentive to misrepresent this and to take advantage of their customers, who are typically uninformed and cannot figure out the poor quality of advice. Regulation is then needed to make sure that this conflict of incentives is dealt with. In early work, Ottaviani (2000) built a model of financial advice, where an informed agent (financial advisor) provides information to investors who are otherwise uninformed and have an uncertain degree of strategic sophistication. The emphasis was on deriving incentives for truthful information disclosure and information acquisition. In a recent pioneering paper, Inderst and Ottaviani (forthcoming) analyze 'misselling', i.e. the practice of misdirecting clients into buying a financial product that is not suitable for them.

Their model hinges on the conflict between sales agents' incentives to prospect for customers and to provide adequate advice to them on whether to buy a particular product. There are certain types of customers for which the financial product is unsuitable and to whom the advisor should not sell it. The conflict of interest between agent and customer arises endogenously from the agent's compensation set by the firm. There is also conflict of interest between the firm and the agent. If the product is sold to the wrong people, there is a probability with which the firm receives a complaint and a policy-determined fine that it has to pay, part of which goes to the disgruntled customer. The firm must ensure that its agents comply with its internal suitability standards when advising customers. It chooses these standards by trading off the benefits from a sale (net of the expected ex post losses associated with misselling) with the agency costs of inducing the agent to uphold the standards. When the sales force requires steeper incentives (for example, as competition for customers intensifies), ensuring compliance with a given standard becomes more costly for the firm. Faced with a higher marginal cost of compliance, the firm 
gradually becomes more permissive towards potential misselling. In equilibrium, standards are affected by several factors, such as the difficulty in attracting customers, the transparency of the commission structure, and the organization of the sales process. The authors conclude that, when addressing misselling, policymakers must take into account these organizational variables.

While the conflict of interest between selling a product and advising what is best for the customer is important and we also find evidence for it below, at least three important empirical questions arise. First, what exactly can professional advisors contribute to individual investors? Second, whom do they tend to serve? Third, what difference do they make to the accounts they run relative to what investors like their clients could do on their own?

Regarding the first question, an issue that has received considerable attention in existing empirical literature is whether professional analysts and advisors have an informational advantage to contribute to individual investors when it comes to predicting stock price movements. Ever since Cowles (1933), there have been questions regarding the ability of stock market forecasters and analysts to predict movements in the stock market. Early studies include Barber and Loeffler (1993) on The Wall Street Journal's Dartboard column, Desai and Jain (1995) on “Superstar” money managers in Barron's, Womack (1996) on brokerage analysts, and Metrick (1999) on investment newsletters.

For example, Womack (1996) examines stock price movements following 'buy' or 'sell' recommendations by fourteen major U.S. brokerage firms. He documents significant price and volume reactions in the direction of the recommendation within a three-day interval, as well as significant post-recommendation stock price drift in the forecast direction, especially for new 'sell' recommendations. He concludes that there is value to these recommendations viewed as returns to information search costs. He also notes, however, that new 'buy' recommendations occur seven times more often than 'sell' recommendations, suggesting that brokers are reluctant to issue sell recommendations, both in order to avoid harming potential investment banking relationships and to maintain future information flows from managers.

Metrick (1999) analyzes a database of recommendations of 153 investment newsletters and finds no evidence that newsletters have superior stock-selection skill, either over short or long horizons. Average abnormal returns are close to zero and the best-performing newsletter under each return model the authors employ does not seem unusual given the sample size. 
Anderson and Martinez (2008) examine abnormal returns realized by brokers in Sweden, on purchases and sales during a window around changes in their stock recommendations. They find that brokers or their clients tend to trade in the direction suggested by broker recommendations, making profits on average around positive recommendation revision dates but not around negative revisions. A sizeable share of the abnormal profits results from transactions before the recorded recommendation date, suggesting that tipping of customers may be taking place. Given the small size of estimated yearly profits from acting on buy recommendations, both in absolute terms (only $0.04 \%$ in yearly performance of total Swedish equity fund assets under management) and relative to the net transactions actually executed by recommending brokers, the authors wonder whether clients are fully compensated for the costs of commissions charged by brokers.

All in all, these papers indicate whether there are gains to be had by clients following strategies that take into account analyst recommendations, in the absence of transactions costs. Barber et al. (2001) take a more investor-oriented approach and examine whether investors can earn positive abnormal profits on these strategies after accounting for transactions costs. They analyze abnormal gross returns that would result from purchasing (selling short) stocks with the most (least) favorable consensus recommendations, in conjunction with daily portfolio rebalancing and a timely response to recommendation changes. Although they find that such strategies would yield annual abnormal gross returns greater than four percent, they also show that high trading levels are required to capture these excess returns. Once the transactions costs entailed by these strategies are taken into account, abnormal net returns for these strategies are not statistically significant.

Begrstresser, Chalmers and Tufano (2008) compare performance of mutual fund 'classes' distinguished by their distribution channel: directly sold to investors versus sold through brokers, with correspondingly different fee structures. They find that funds sold through brokers offer inferior returns, even before the distribution fee, no superior aggregate market timing ability, and exhibit the same return-chasing behavior as observed among direct-channel funds. Finally, more sales are directed to funds with larger distribution fees.

The general impression given by the literature on informational contributions of analysts or brokers to direct stockholding is that these may be present but unlikely to be exploitable by individuals given the trading costs they entail. However, some researchers take a different angle 
and point out that, even if professional advisors do not have superior information that is exploitable for the normal trading within an individual account, they may be less likely to exhibit behavioral biases that hurt account performance. They could thus help either by running the account themselves or by encouraging investors to behave appropriately.

A behavioral bias that has received considerable attention is the 'disposition effect', i.e. the tendency of some individuals to sell winners and keep losers when it comes to direct stockholding (Odean 1998). Shapira and Venezia (2001) found that the disposition effect is significantly less pronounced among professional than among self-directed investors.

Well trained IFAs might be able to ameliorate behavioral biases of their clients and moderate trading activity (Campbell and Viceira, 2003). Barber and Odean (2000) show that some investors trade excessively in brokerage accounts, suffering transactions costs that result in significantly lower returns. Such behavior is often attributed to overconfidence, especially pronounced among male investors (Odean, 1998; 1999; Barber and Odean, 2001; Niessen and Ruenzi, 2008). Shu et al. (2004) analyze the returns on common stock investments by 52,649 accounts at a brokerage house in Taiwan for 45 months ending in September 2001. They find a U-shaped turnover and performance relation rather than the monotonic one predicted by overconfidence: the most frequent traders in the top turnover quintile perform better than investors in the middle three quintiles. Other behavioral biases have been found to influence some individual investors, such as trading on the basis of past returns, reference prices, or the size of gain or loss over the holding period (Grinblatt and Keloharju, 2001).

While the list of potential behavioral biases can grow longer, an important question consistent with our approach in this paper - remains as to whether individuals who exhibit such biases are likely to make use of professional investors. For example, Guiso and Japelli (2006) argued that overconfidence (i.e. the disposition of investors to overstate the value of their private information) reduces their propensity to seek advice. Indeed, the Barber and Odean data come from a discount broker that does not offer advice. Even if overconfident traders approach financial advisors, one might wonder whether financial advisors who earn sales commissions would actually discourage them from executing too many trades without some incentive scheme.

On the other hand, financial advisors may help correct behavioral biases or investment mistakes when such correction is aligned with their interests. A case in point is diversification. A 
number of empirical studies find that many individual investors hold undiversified portfolios (see e.g. Blume and Friend, 1975; Campbell, 2006; Goetzmann and Kumar, 2008). Financial advisors who earn commissions for selling mutual funds have an incentive to promote such sales and through them diversification of their client's accounts.

Our paper takes a more direct approach to the issue of the role and contribution of financial advisors than previous research. Recognizing both the potential informational advantage and the potential contribution of professional investors to controlling behavioral biases and correcting investment mistakes, it compares directly what investors actually accomplish on their own versus to what they accomplish with the guidance of a financial advisor, net of transactions costs. It does so with reference not to theoretical portfolios of individual stocks, but to portfolios actually chosen and adjusted by investors, which may include directly held stocks, bonds, and mutual funds; and it accounts for a number of investor characteristics observable in our data and for how they influence the tendency to use a financial advisor.

\section{Data}

\subsection{The Discount Brokerage Firm and Financial Advisors}

The primary data set we are using in this study is administrative information from a large German discount brokerage firm. It covers the investments of 32,751 randomly selected individual customers who opened an account with the brokerage firm prior to January 2001 and kept the account active through June 2006. If customers opened multiple accounts we consolidated them into one single account.

For each sampled customer we have information on date of birth, gender, marital status, profession (including status as employed or self-employed), zip-code of place of residence, nationality, and self-reported security-trading experience in years. ${ }^{1}$ All information was collected by the brokerage firm on the date of account opening and updated according to new information that the firm has obtained from the customer in the interim. Table 1 shows descriptive statistics

\footnotetext{
${ }^{1}$ Self-reported trading experience is reported on a scale with intervals equal to five years. We construct a variable that has the interval midpoints as values and then add the number of years between account opening date and January 2001 to measure trading experience at the beginning of our observation period.
} 
of our sample, after dropping accounts that report age of account owner below $18 .^{2}$ As shown in the Table, 77.8 percent of account owners were male, and 47.8 percent married. Overall, 86.1 percent were employed, 13.2 percent self-employed, and 0.7 percent public servants, retirees, housewives or students. Average trading experience as of January 2001 was 7.56 years. For each sampled customer account, we record all trades and all monthly position statements over the entire observation period. Trading records indicate type (i.e. sale, purchase, dividend payment, etc.), currency, trading channel (e.g. internet, telephone, fax, etc.), and execution date.

Importantly, transaction amounts are net of any transactions costs and provisions charged by the brokerage house or the IFA and processed through the brokerage house. ${ }^{3}$ Transaction costs and provisions are divided between the brokerage and IFA, with the bank typically earning roughly 30 basis points for transaction fees, account maintenance, and front loads, leaving about 170 basis points for the IFA. There is a minority of advisors who follow a different business model: instead of earning front loads, they forward those to their clients and earn a flat fee as a percentage of account volume. As this flat fee is not run through the bank, it is not observed by us and it is not taken into account in computing returns and other measures of performance net of costs. Since we obtain negative effects of IFAs on account performance in econometric estimation below, the resulting understatement of costs in these cases, if anything, strengthens our findings on the role of IFAs.

The monthly position statements list for each item the type of security (e.g. stocks, bonds, mutual funds etc.), the number of securities, and the market value per security at month end. At the start of the observation period, average annual account volume was 10,015 Euro. We computed monthly turnover by dividing the combined transaction value of all purchase

\footnotetext{
${ }^{2}$ These are typically accounts run by parents on behalf of their children. Specifically, 796 investors in our original sample were younger than 18 on September 5, 2006, and the youngest investor in that sample was just under 6 years old. Tax advantages for parents arise because during the observation period there was a threshold level of interest or dividend income above which capital income tax needed to be paid. We have also run the regressions including investors under 18, but our results were hardly affected in terms of sign, significance, and even size of estimates, except for small changes in the estimates for age categories.

${ }^{3}$ Although we do not observe costs separately in our data, we know from the data provider that the bank and the IFA combined earn typically 100-200 basis points on clients with account volume greater than 50,000 Euros. For smaller accounts, this number is typically in the neighborhood of 200 basis points, although it can be as high as 300-500 basis points, due to front loads and kick-backs from mutual funds.
} 
transactions for a given month by the average of beginning-of-month and end-of-month account volume. Average monthly turnover was 4.7 percent in our sample.

In order to get some idea of the composition of portfolios in the accounts of the brokerage firm, we report that on average (not excluding account owners aged under 18) sample customers held 38.6 percent of account volume in the form of equity mutual funds, 47.4 percent in the form of single stocks (28 percent thereof in German stocks), 2.4 percent in the form of bond mutual funds, 3.8 percent in the form of single bonds and the remainder in the form of structured investment certificates, warrants, and other assets.

Our administrative data set includes a variable that indicates whether a given brokerage customer is also a client of an IFA who registered with the brokerage firm. We know from the brokerage firm that, typically, advised customers were brought to the brokerage house by IFAs. About $90 \%$ of IFAs registered with the internet broker are former employees of commercial banks advising customers on investment accounts. They decided to leave the bank and become independent, thereby offering lower costs than banks and greater choice of financial products. Thus, they were able to persuade many of their former customers at the bank to transfer investment accounts to the brokerage firm. The remaining $10 \%$ of IFAs in our sample are not former bank employees but directly joined a larger team of IFAs and built up their own customer base, again drawing mostly from former bank customers.

At the time of account opening, IFAs had typically obtained a client mandate to place orders on behalf of the client. We do not have information on which clients fully delegate trading decisions to their IFAs and which only consult their IFAs for guidance and then place trades themselves. The brokerage firm offers several compensation schemes to IFAs. Only for a negligibe fraction of IFAs are revenues dependent solely on assets under management. More than $90 \%$ of IFAs generate at least a portion of revenues from trades, such as sales commissions . In the case of mutual funds the commission is a function of the upfront load the brokerage firm earns from the fund producer.

Of the customers in our sample, 12.7 percent consult IFAs registered with the brokerage firm. More than half of these customer are IFAs’ former banking clients, with the remaining half (typically also former bank customers) having been acquired over the years, most importantly through existing customers' referrals. We cannot rule out that (presumably other) customers 
obtain professional advice from outside advisors. This is, however, rather unlikely because such outside advisors do not participate in the fees and commissions paid by the client to the brokerage firm and must therefore charge their services on top of the full brokerage fees and commissions. Table 1 shows how the demographics of IFA clients compare with those in the overall sample and those without an IFA. We see that the IFA sample contains somewhat larger proportions of older $\left(50^{+}\right)$customers, with greater experience and larger initial size of accounts, on average. Self-employed and female customers are more heavily represented in the IFA sample than in that without IFA.

A crucial issue in estimating the effect of IFAs on account performance is the endogeneity of the choice of consulting a financial advisor. This choice is likely to be correlated with account performance and to bias the econometric results. For instance, clients who are more risk averse might be more likely to consult an IFA as well as to invest in a safer portfolio; richer clients might also be more likely to consult IFAs and to have different investment strategies. In order to handle this endogeneity issue, we used regional instruments in a second data set we retrieved from the destatis files of the German Federal Statistical Office, which provides a broad set of structural data on some 500 German regions. We obtained size of region in square kilometers, population per region, total disposable income per region, disposable income per capita per region, fraction of college graduates and average voter participation in communal, state and federal elections per region. The system of German zip codes is more granular than the regional grid of destatis. We mapped customer accounts to regions by assuming that all zip-codes in the same destatis region share the same structural characteristics. Finally, we augmented our second data set with the number of bank branches per destatis region, which we acquired from a commercial data provider.

\subsection{Measuring Account Performance}

In this paper we are interested in the effect of financial advice on portfolio performance and portfolio risk. In order to compute monthly portfolio returns, we assume as in Dietz (1968) and that all transactions occur in the middle of a given month: 


$$
R_{p, t}=\frac{\left(V_{p, t}-V_{p, t-1}\right)-\left(P_{t-1 \rightarrow t}-S_{t-1 \rightarrow t}\right)+E_{t-1 \rightarrow t}}{V_{p, t-1}+\left(\frac{P_{t-1 \rightarrow t}-S_{t-1 \rightarrow t}+E_{t-1 \rightarrow t}}{2}\right)}
$$

where:

$$
\begin{aligned}
& V_{p, t} \quad=\text { market value of portfolio } \mathrm{p} \text { at end of month } \mathrm{t} ; \\
& P_{t-1 \rightarrow t} \quad=\text { market value of all purchases (including fees) between } \mathrm{t} \text { and } \mathrm{t}-1 ; \\
& S_{t-1 \rightarrow t} \quad=\text { market value of all sales (including fees) between } \mathrm{t} \text { and } \mathrm{t}-1 ; \\
& E_{t-1 \rightarrow t} \quad=\text { cash proceeds from dividends, coupons etc. received between } \mathrm{t} \text { and } \mathrm{t}-1 .
\end{aligned}
$$

Monthly returns from (1) are winsorized by treating returns that fall into the first or the $100^{\text {th }}$ percentile as missing values. ${ }^{4}$ We construct log returns and use them and the standard regression model in (2) to estimate abnormal (log) returns for each portfolio.

$$
r_{p, t}-r_{f, t}=\alpha_{p}+\beta_{p}\left(r_{M, t}-r_{f, t}\right)+\varepsilon_{p, t}
$$

where:

$$
\begin{array}{ll}
\alpha_{p} & =\text { estimated abnormal return (Jensen’s Alpha) for portfolio } p ; \\
\beta_{p} & =\text { estimated market beta for portfolio } p ; \\
r_{M, t} & =\log \text { return of the Euro-denominated MSCI-World Index in month } t ; \\
r_{f} & =\log \text { return on the one-month Euribor; } \\
\varepsilon_{p, t} & =\text { error term of regression for portfolio } p .
\end{array}
$$

We also decompose total portfolio risk into systematic risk and unsystematic risk:

$$
\sigma_{p}^{2}=\beta_{p}^{2} \sigma_{B}^{2}+\sigma_{\varepsilon, p}^{2}
$$

\footnotetext{
${ }^{4}$ Extreme monthly return observations were treated as missing (and not set to the upper/lower boundary that would be customary for Winsorization) because a) they most likely represent erroneous data, and b) we do not lose customers but just single months. As a consequence, some customers have only 63 or 64 instead of 65 monthly return observations.
} 
where

$$
\begin{array}{ll}
\sigma_{p}^{2} & =\text { total variance of log returns of portfolio } \mathrm{p} ; \\
\beta_{p}^{2} & =\text { square of estimated benchmark beta for portfolio } \mathrm{p} ; \\
\sigma_{B}^{2} & =\text { variance of log returns on benchmark portfolio B (MSCI-World index); } \\
\sigma_{\varepsilon, p}^{2} & =\text { variance of error term from the regression in (2). }
\end{array}
$$

The first term on the right hand side of (3) measures systematic risk and the second term measures diversifiable portfolio risk. In our regressions, we use the portion of diversifiable risk in total risk:

$$
\frac{\sigma_{\varepsilon, p}^{2}}{\sigma_{p}^{2}}=\frac{\sigma_{\varepsilon, p}^{2}}{\beta_{p}^{2} \sigma_{B}^{2}+\sigma_{\varepsilon, p}^{2}}
$$

We also consider the probability that returns fall short of some target return. This is a special case (for $n=0)$ of lower partial moments $\left(\mathrm{LPM}_{\mathrm{n}}\right)$ of returns as measures for (downside) risk:

$$
L P M_{n}=\sum_{x=-\infty}^{\tau} P(X=x)(\tau-x)^{n}
$$

where $\tau=$ monthly target return (we use 0 or -5 percent p.a.) and $n$ is the order of the moment.

\section{Performance Record of Financial Advisors}

For many clients, a natural first step towards deciding whether to use an IFA or not would be to compare the historical performance of accounts run with IFA involvement and those run without it. Even in the absence of official records (indeed our internet broker does not compute or print performance records of the two types of accounts), prospective clients may still be influenced by the experiences of existing clients through word of mouth or summary descriptions by the IFA. In this Section, we make use of our extensive sample and ask how IFA accounts (defined as those that benefit from the input of IFAs collaborating with the brokerage firm, which ranges from mere consultation to full responsibility for trades) have performed over the observation period compared to those run without input from IFAs. 
Figure 1 plots histograms of average monthly log returns over our observation period for accounts that were self-managed and for those run with IFA input. We see clearly that the IFA accounts exhibit more mass towards the center and higher end of the distribution, indicating better performance. Table 1 shows monthly logarithmic returns. The sample mean log (gross) return on IFA accounts is considerably higher than that of self-managed accounts: - $.44 \%$ versus $.80 \%$. Interestingly, IFA customers were getting on average a return net of all transactions costs that was comparable to what they would have gotten if they had invested in the DAX for the duration of our sample period.

A refinement to this statement could be made by looking at any excess return over and above what standard finance models would justify on the basis of covariance with the market portfolio. Jensen's alpha (the average excess of realized returns relative to the security market line) is compared in Figure 2 for the two sample groups. We observe that excess returns of investors with IFA exhibit much greater concentration around zero than what is shown for self-managed accounts. IFA accounts tend also to be closer to the security market line than individual investors, certainly from below. This suggests that they may be using the market line as a performance benchmark: they do not want to be found under it, but they also do not feel compelled to exceed it systematically compared to what individuals tend to accomplish on their own. Table 1 confirms that IFA accounts can claim a higher average excess return on accounts run with their input, as well as a higher average return.

These higher returns offered by IFAs are not associated with more risk in the portfolio. Table 1 shows that the overall portfolio risk of IFA accounts is about two thirds of that of non-IFA accounts; unsystematic risk is twenty percent lower for IFA accounts; and the beta coefficient capturing covariance with the market portfolio (proxied by the MSCI World Index) is two thirds of its value without IFA involvement, implying that systematic risk is also two thirds. Figure 3 shows that the distribution of total portfolio variance under IFAs is 'squeezed' towards values closer to zero compared to what is produced by individuals managing their accounts. The distribution of betas is also much less skewed and more symmetric under IFAs (Fig. 4); the same holds for unsystematic risk (Fig. 5).

Some prospective clients may pay particular attention to the probability of making losses or substantial losses. This would be particularly evident with loss aversion utility or rank-dependent 
utility, but even under expected utility clients could be influenced by very bad states because of high marginal utility of consumption in those states. IFA accounts have exhibited, on average, lower probabilities of losses or substantial losses. Table 1 shows that the fraction of investors that exhibited a loss (the return is negative) over a month is 48 percent for investors with IFA and 45 percent without (45 and 40 percent, respectively, for substantial losses). If one compares the distributions of these probabilities in Figure 6, IFA accounts look like some mass has been displaced from values between .4 and .5 to values between .3 and .4 , which seems to speak in favor of IFA accounts.

Comparison of IFA and non-IFA accounts also shows that frequency of trades is smaller among IFA accounts, but average portfolio turnover (which is sensitive to the size of purchases) is much greater. The average monthly number of trades per 1000 euro of account volume is .32 for IFA and .44 for non-IFA accounts, but the turnover rate is more than double for IFA accounts. Looking at Figures 7 and 8, IFA accounts tend to be clustered closer to zero trades per year standardized by account volume, but to be distributed away from zero in terms of turnover. In other words, IFAs get commission based on the volume of purchases and tend to exhibit greater purchases than individual clients on average, but they do not do so by pushing the trading button more often. IFA accounts tend also to be larger, and are therefore associated with larger positions and trades.

Finally, IFA accounts tend to exhibit far greater diversification than those run by individuals alone. The average share of directly held stocks among self-managed accounts is just under 60 percent, while that for IFA accounts is about 20 percent. Given incentives to sell mutual funds that IFAs have, this is not surprising. However, based on performance records, it is not even harmful: it does not seem to hurt either average portfolio returns or any risk measure.

All in all, performance records paint a very positive view of IFA account performance: IFA accounts have offered greater returns, both in total and relative to the security market line; lower risk, systematic and unsystematic; lower probabilities of losses and of substantial losses; and greater diversification. The deeper question is, of course, whether these differences are due to IFAs themselves or to the customers they tend to attract. It is to this that we now turn. 


\section{Who Has a Financial Advisor?}

We first consider which characteristics of the brokerage firm client contribute to the client's account being run with input from an IFA. A priori, two very different cases seem plausible. One is that IFAs tend to be matched with smaller, younger investors, to whom they promise to offer knowledge and guidance that will help avoid mistakes and improve account performance. Another is that IFAs tend to be matched with wealthier, older investors who can benefit from IFA services by saving valuable time and/or by improving returns on sizeable investments.

Table 2 reports probit regressions of whether the client makes use of an IFA on a number of factors; rather than the original coefficients, we report marginal effects. The first column uses as regressors only characteristics of the client. We see that an extra year of self-reported experience with the relevant financial products actually increases the probability of using an IFA. Being self-employed increases the probability of IFA use by a sizeable amount of about 6.5 percentage points, while there is no significant effect for employees relative to remaining occupational categories in the population. Given other characteristics, males are less likely to use an IFA, suggesting an analogy to the role of gender in trading behavior and reinforcing the view that males tend to have more (over)confidence in their ability to run financial investments. Married clients are also less likely to use an IFA, controlling for other factors, probably because spouses can be used as sounding boards both for investment decisions and for whether an IFA should be hired. We also find that clients over 60 years of age have a significantly greater probability of using an IFA, by about 15 percentage points. The comparison group for age dummies (i.e. the excluded category) is investors younger than 30 years old but above 18 .

Column 2 uses the same regressors but controls also for account volume at the very start of the observation period. This serves as a scale or 'wealth' variable, and we focus on the beginning-of-period value to minimize endogeneity problems running from the use of IFA to account volume. Introduction of this control has small influence on estimated marginal effects, except for lowering the contribution of old age and eliminating statistical significance of experience on the choice to use an IFA, suggesting that these were partly proxying for wealth. 
In column 3 we control also for features of the region where the client is located, constructed from primary information on zip codes. Being located in a region with a larger fraction of college graduates substantially reduces the probability of using an IFA; a small marginal effect in the same direction is found for higher income regions. This could be due to two, not mutually exclusive, factors. First, IFAs are less needed because these regions have greater concentrations of educated, high-income neighbors from whom they can learn. Second,

IFA supply is not proportional to college graduates and high-income households, so that each given client is less likely to be approached by an IFA and finds it more difficult to secure one in competition with many other attractive clients. Importantly, however, marginal effects of own client characteristics are hardly affected when we also control for regional variables.

Based on these findings, we conclude that IFAs tend to be matched with wealthier and

older investors. These investors have good reasons to want to delegate to IFAs, such as high opportunity cost or low inclination to spend a lot of time managing investments, as well as sizeable wealth holdings. On the supply side, the fact that most IFAs and about half of IFA customers had a former banking relationship puts IFAs in an eminent position to select wealthier clients. IFAs seem to have chosen to go for the big players who have a lot to invest rather than for the younger, smaller or inexperienced investors who have a lot to learn.

\section{Financial Advice and Portfolio Performance}

We now turn to how IFA use affects various aspects of account performance once we control for client characteristics. OLS regressions, reported in the Appendix, yield results consistent with the performance records we reported above. However, since use of an IFA not only affects but could also be motivated by account performance, such results could be misleading as the IFA variable has not been instrumented.

We carry out instrumental variable estimation, using as instruments the following variables (recorded at the broader region level and assigned to each customer based on the customer's zip code): bank branches per capita, log income in the region, voter participation, and fraction of the population with college degree. As usual, the assumption is that these regional variables can 
influence the choice of whether to use an IFA or not but they affect individual account performance only through that choice and not directly. The standard errors of the estimates are corrected for clustering at the zip code level.

To assess the quality of our instruments we perform the test of over-identifying restrictions and the rank test. In each of the regressions, the Hansen-Sargan test does not reject the overidentifying restrictions: the p-values associated with the test always exceed 5 percent, except in the case of the regressions for log returns (p-value of 0.045) and Jensen's alpha (p-value of 0.029), where they exceed 1 percent. We also check the rank condition testing the null hypothesis that the coefficients of the four instruments are jointly equal to zero in the first-stage regression. The F-test (37.44) rejects this null at 1 percent level and implies that the rank condition is satisfied.

\subsection{Portfolio Returns}

We first examine the difference that having an IFA makes to the average return on the account over the 66-month observation period, after all transactions fees have been paid to the broker. The first two columns of Table 3 show the relevant instrumental variables regressions for total returns on the account. Whether we control for initial account volume or not, the contribution of an IFA to the total account return is negative, once we control for observable characteristics of the account owner.

Years of experience contribute to higher total return. This is consistent with some recent studies indicating that the magnitude of investment mistakes decreases with sophistication and experience (see e.g. Grinblatt and Keloharju, 2001; Zhu, 2002; Feng and Seasholes, 2005; Lusardi and Mitchell, 2007). For example, Feng and Seasholes (2005) ask whether investor sophistication and trading experience eliminate behavioral biases, such as the disposition effect, using data from the PR of China. ${ }^{5}$ They conclude that sophistication and experience eliminate the

\footnotetext{
${ }^{5}$ They proxy sophistication mainly by the number of trading rights (indicating the number of methods to trade) and an indicator of initial portfolio diversification, both at the start of the observation period. Experience is proxied by the number of positions taken by investor $i$ up until $\mathrm{d}$ ate $t$, a time-varying covariate.
} 
reluctance to realize losses, but only reduce the propensity to realize gains by $37 \%$. Male gender detracts from account returns, consistent with the literature on overconfidence.

Is it the case that IFAs create value for their customers by increasing the return they get over and above what the security market line implies? Columns 3 and 4 report similar regressions for Jensen's alpha, namely the excess return, first without and then with controls for account volume. In both cases, the IFA contribution is negative, once the characteristics of the account owner are taken into account. The patterns of sign and significance, as well as how these are affected by the scale variable are very similar to those for total returns.

The implication of our findings in this section is that involvement of IFAs with these brokerage accounts tends on average to reduce both the total portfolio return and the excess return, once the characteristics of the owner are taken into account. This reverses the impression from performance records that IFAs improve performance and is quite consistent with our findings in the section on who has an IFA. On the basis of these findings, IFAs tend to be matched with the older and wealthier account owners. Those who choose to collaborate with an IFA end up obtaining lower returns than what their peers obtain who do not involve IFAs in the running of their brokerage accounts.

\subsection{Volatility of Returns}

The finding that IFAs tend to lower account returns is not necessarily negative by itself. It is a priori conceivable that IFA involvement lowers returns in exchange for ensuring that clients are exposed to smaller portfolio risk. We therefore turn next to the effect of IFA involvement on different measures of return variance on the account. Table 4 reports our findings.

Columns 1 and 2 regress total variance of portfolio returns from equation (3) above on the instrumented IFA dummy and the remaining client characteristics, as in the case of returns. We find no evidence of a systematic moderation of total account risk when an IFA is used. Indeed, use of an IFA is estimated to have a positive and significant effect on total portfolio variance, regardless of whether we control for account volume.

Other variables that consistently contribute to greater return volatility are being male and young. Investors’ experience and being married tend to moderate total return variance, but by a 
small amount. Account volume, when included, is associated with smaller variance, presumably because it allows greater diversification. ${ }^{6}$

As equation (3) indicates, overall portfolio variance can be decomposed into systematic, resulting from the extent to which the account covaries with the market portfolio ('beta”), and unsystematic. We investigate impact on each type of risk separately (columns 3 to 6 in Table 4). Involvement of IFAs contributes to both types of risk, regardless of whether we control for account volume.

Being male increases both types of risk. Experience has a statistically significant moderating effect on both types of risk, though the effect is quantitatively negligible for unsystematic risk. Bigger accounts tend to exhibit less of both types of risk.

All in all, accounts run by financial advisors have lower returns and higher portfolio variance, which implies lower risk-adjusted returns. However, use of IFAs is not the only factor that simultaneously lowers returns and increases risk: other factors, such as being male or having limited experience, also contribute in this direction.

\subsection{Probabilities of Losses}

If use of IFAs does not increase returns, excess returns, or returns adjusted for risk, maybe it limits the probability of losses or substantial losses. This could be particularly relevant for clients who are disproportionately concerned about bad outcomes. Table 5 reports our findings regarding determinants first of the probability of a negative portfolio return and then of the probability of a negative return of more than 5 percent per month in absolute value.

Controlling for client characteristics, IFA accounts tend to exhibit higher probabilities of losses and higher probabilities of losses of more than 5 percent per month. Estimated IFA contributions to these probabilities are of the order of 7 percentage points for losses, and 9 percentage points for losses of more than 5 percent monthly. The finding that point estimates and statistical significance are greater for the probability of substantial losses than for the probability of any loss makes it difficult to argue that IFAs help prevent disasters.

\footnotetext{
${ }^{6}$ We find below that larger accounts have smaller share of directly held stocks.
} 
Controlling for other factors, being male contributes to greater probabilities of losses and of substantial losses, by 1.5 to $2 \mathrm{pp}$, and the estimated contribution of this factor is hardly sensitive to whether we control for account volume or not. This extends usual results of being male on portfolio returns to risk and to the likelihood of substantial losses. An additional year of financial experience has a strongly significant moderating effect on probabilities of any loss and of sizeable losses, but estimated effects are small, implying that large differences in experience are necessary for sizeable reductions in the probability of losses. Being older than 60 also lowers the probability of losses, but much of the effect appears to be due to larger account volumes associated with old age. Young investor age (between 30 and 40) is found to have a positive but small effect on the loss probabilities. This is of some interest, but given the cross-sectional nature of our data on account performance, disentangling age from cohort and time effects is problematic. Controlling for other factors, account volume tends to reduce the probability of both types of losses, presumably because it makes it more likely that the account is diversified. All in all, we fail to find evidence of a positive effect of IFAs even in reducing the probability of losses or of substantial losses on the account.

\section{Going Behind the Scenes: Trading, Turnover, and Diversification}

Given our results on returns and risk, it is natural to ask what type of behavior underlies them. Recent literature has stressed overtrading as a powerful source of account underperformance, precisely because of the additional trading costs it imposes on the account owner. In our present context, IFAs get commissions mainly when the account owner purchases mutual funds. Although this does not create an overall incentive for overtrading, it creates an incentive to the IFA to encourage the account owner to make fund purchases.

The first column of Table 6 examines the effect of IFA on the number of purchases per month. These purchases exclude corporate actions, periodic saving plan investments and portfolio transfers, so as to be more directly linked to the IFA incentives to sell specific financial instruments. We standardize the number of purchases by account volume as a scale variable (although we add back account volume as an additional regressor in some specifications). Our 
results imply a positive effect of IFA on the standardized number of purchases, consistent with their incentives. As purchases result in transactions costs, they contribute to lower realized returns on the account net of these costs. The regression also confirms the positive role of male gender found in other studies (see above). Financial experience is found to have a strongly statistically significant effect in moderating the frequency of purchases, albeit the effect of a single additional year of experience tends to be small. This finding is consistent with the finding of Dorn and Huberman (2005) that survey respondents with longer investment experience trade substantially less.

Commissions are linked to the size of purchases and not merely to their frequency. The $3^{\text {rd }}$ and $4^{\text {th }}$ columns of Table 6 examine the effect of IFAs on average account turnover over the observation period, defined in terms of purchases so that it relates to IFA incentives. They show a strongly statistically significant effect of IFAs on increasing account turnover. This could be part of the explanation for why IFAs contribute negatively to portfolio returns. ${ }^{7}$ Again, males are more likely to have larger account turnover, ${ }^{8}$ but small positive effects are found, somewhat surprisingly, for married account owners. This parallels the effect of being married on the standardized frequency of trading and may be reflecting a greater frequency of life changes that require portfolio rebalancing, especially since we are not able to control for household size, number and ages of children, etc. Self-employed customers tend to have lower turnovers than the rest, maybe because they have less time in their hands to evaluate purchases. Experience discourages turnover, although the effect of a single-year difference tends to be small. Younger investors are estimated to have higher turnovers, as they actively expand their portfolios, while the opposite finding holds for those above 60.

A different perspective on the possible role of IFAs refers to their role in encouraging diversification of the account. We would expect this to have a first-order effect on portfolio

\footnotetext{
${ }^{7}$ Higher turnover might be motivated simply by commissions but also by an incentive of IFAs to justify their fees by rebalancing client portfolios (see e.g. Lakonishok et al., 1992).

${ }^{8}$ Indeed, Niessen and Ruenzi (2006) show gender effects even for fund managers. According to their estimates, portfolio turnover is lower for female than for male fund managers.
} 
return variance, although it is also likely to affect returns as well. Given the incentives of financial advisors to sell mutual funds, we examine the average share of directly held stocks in the account over the 66-month observation period. Regardless of whether we control for account volume, we find no significant effect of IFA on this share, although the point estimate is negative. Thus, the apparent effect of IFAs on diversification based on performance records is not found to be statistically significant when the nature of matching between IFAs and clients is controlled for.

Controlling for other factors, male account owners tend to have a tendency to put larger shares of their account in directly held stocks; being married tends to have the opposite effect, presumably because more people are at risk and maybe vocal in encouraging diversification. Employees and self-employed account owners tend to invest more in directly held stocks, probably because of their increased social interactions and the greater likelihood of receiving relevant information in the course of their everyday business. Interestingly, experience tends to lower the share of directly held stocks, indicating that experience works more as a factor

dampening overconfidence than as one that encourages account owners to handle the usually more difficult task of managing direct investments in stocks. We find no indication that older age groups invest less in directly held stocks (indeed, we find the opposite effect for account owners in their 50s), but we cannot distinguish age from cohort effects in our cross-sectional data.

The conclusion from the regression analysis is that IFAs seem to encourage frequent trading and large turnover buy do not appear to have a significant effect on the fraction of the account invested in directly held stocks.

\section{Conclusions}

We have investigated whether individual investors tend to produce better account performance on their own rather than with the help of an independent financial advisor. Our data track accounts of a major internet brokerage for a large number of randomly selected individual customers over a period of 5.5 years, who may or may not invest their portfolio with the help of an independent financial advisor (IFA). As suggested by sample statistics and confirmed by 
regression analysis, advisors tend to be matched with richer, older investors rather than with poorer, younger ones.

As for the role of advisors, we find a marked contrast between performance records and econometric results. While performance records depict a positive picture of IFA, once we control for investors' characteristics and the endogenous choice of IFA we find that accounts run by or with input from financial advisors offer on average lower returns, both in total and relative to the security market line; higher risk, systematic and unsystematic; and higher probabilities of losses and of substantial losses; and not significantly greater diversification through investments in mutual funds rather then in single stocks. Higher trading costs and the associated commissions earned by IFA are likely to explain why IFA-accounts under-perform. In fact, we find that IFAaccounts feature more frequent trading and higher portfolio turnover relative to non-IFA accounts.

Our results provide a new perspective on the role of financial advisors that might be useful for theoretical and policy analysis of their conflicting incentives, their likely effects, and the need to regulate them. Based on our findings, it should not be taken for granted that financial advisors provide their services to small, young investors typically identified as in need of investment guidance. Indeed, for the internet broker data we consider, the opposite is true. It is a matter of further research if advisors for more broadly held financial products tend to offer their services to inexperienced investors, and what effect they have on performance. However, the fact that IFAs in our sample typically had experience as bank employees advising customers makes it more likely that our conclusions transfer to advisors employed by banks to run investment accounts of their customers. At any rate, with commissions based on the volume of purchases, the costs of persuading small investors to purchase probably need to be very low before such investors provide a profitable hunting ground for financial advisors.

A further important policy issue is whether financial advice is a substitute for financial literacy and sophistication. Given the rapidly growing literature on investment mistakes, providing financial advice to inexperienced, naïve investors could have been an alternative to trying to educate them in financial matters. Our findings caution against relying on this alternative when financial advisor incentives and tendencies of inexperienced clients result in relatively few matches. Other alternatives, such as simpler products and carefully designed 
default options, may be more promising than financial advice in averting negative distributional consequences.

Our findings imply that financial advisors end up collecting more in fees and commissions than any monetary value they add to the account. This raises the further question of whether advisors overcharge and should be regulated. One possibility is that investors who delegate portfolio management observe that they obtain the market return on average, but don't realize that they would obtain a higher return if they managed the portfolio themselves. This interpretation would support financial regulation to protect investors from mis-selling practices. However, our findings do not rule out another interpretation, namely that richer and older investors understand the fee structure, but are willing to delegate account management to advisors because they value their own time and effort more than the foregone performance.

Finally, our comparison of portfolio performance using financial advisors might prove useful for evaluating the recent implementation of the MIFID EU Directive aimed at increasing financial markets transparency and competition. This requires financial institutions to elicit and rate investors' financial abilities through simple questionnaires. In these, investors are asked to report knowledge of specific assets (such as stocks or mutual funds) or, in general, whether they consider themselves financially sophisticated. The directive also aims at avoiding conflicts of interests between individual investors and financial institutions and advisors. Our study suggests that high investor quality does not necessarily eliminate the need to monitor quality of services by financial advisors, especially since we found negative performance effects even for experienced clients. 


\section{References}

Anderson, Anders and Jose Vicente Martinez (2008). "Vice or Advice? Profits from Brokerage Firm Trading around Recommendation Revision Dates”, working paper.

Barber, Brad M.,and Douglas Loeffler (1993). "The 'dartboard' column: Second-hand information and price pressure”, Journal of Financial and Quantitative Analysis, 28, 273-84.

Barber, Brad M. and Terrance Odean (2001). "Boys will be Boys: Gender, Overconfidence, and Common Stock Investment”, Quarterly Journal of Economics, 116, No. 1, 261-92.

Barber, Brad M. and Terrance Odean (2000). "Trading Is Hazardous To Your Wealth: The Common Stock Investment Performance of Individual Investors”, Journal of Finance, 55, No. 2, 773-806.

Barber, Brad M., Reuven Lehavy, Maureen Mcnichols, and Brett Trueman (2001). ”Can Investors Profit From The Prophets? Security Analysts Recommendations and Stock Returns”, Journal of Finance, 56, No. 2, 531-63.

Bergstresser, Dan, J. Chalmers, and Peter Tufano (2008). "Assessing the Costs and Benefits of Brokers: A Preliminary Analysis of the Mutual Fund Industry", forthcoming in the Review of Financial Studies.

Bilias, Yiannis, Dimitris Georgarakos, and Michael Haliassos (2008). "Portfolio Inertia and Stock Market Fluctuations”, NETSPAR Discussion Paper No. 2008-022.

Blume, Marshall E. and Irwin Friend (1975). "The Allocation of Wealth To Risky Assets - The Asset Structure of Individual Portfolios and Some Implications For Utility Functions”, Journal of Finance, 30, No. 2, 585-603.

Campbell, John Y. (2006). “Household Finance”, Journal of Finance, 61, 1553-604.

Campbell, John Y. and Viceira, Luis M. (2003). Strategic Asset Allocation - Portfolio Choice for Long-Term Investors. New York: Oxford University Press.

Cowles, Alfred (1933). “Can Stock Market Forecasters Forecast?”, Econometrica, 1, No. 3, 309-24.

Shu, Pei-Gi, Shean-Bii Chiu, Hsuan-Chi Chen, and Yin-Hua Yeh (2004). "Does Trading Improve Individual Investor Performance?”, Review of Quantitative Finance and Accounting, 22: 199-217.

Desai, Hemang, and Prem C. Jain (1995). “An Analysis of the Recommendations of the 'Superstar' Money Managers at Barron's Annual Roundtable”, Journal of Finance, 50, 1257-274. 
Dietz, Peter O. (1968). “Components of a Measurement Model: Rate of Return, Risk, and Timing”, Journal of Finance, 23, No. 2, 267-75.

Dorn, Daniel and Gur Huberman (2005). “Talk and Action: What Individual Investors Say and What They Do”, Review of Finance, 9, No. 4, 437-81.

Feng, Lei and Mark Seasholes (2005). "Do Investor Sophistication and Trading Experience Eliminate Behavioral Biases in Financial Markets?”, Review of Finance, 9 No. 3, 305-51.

Goetzmann, William N. and Alok Kumar (2008). “Equity Portfolio Diversification”, Review of Finance, vol. 12, no. 3, 433-63.

Grinblatt, Mark and Matti Keloharju (2001). “What Makes Investors Trade?”, Journal of Finance, 56, No. 2, 589-616.

Guiso, Luigi and Tullio Jappelli (2006). “Information Acquisition and Portfolio Performance”, CSEF Working Paper No. 167.

Inderst, Roman and Marco Ottaviani (forthcoming). “Misselling Through Agents”, American Economic Review.

Lakonishok, Josef; Andrei Shleifer, Robert W. Vishny, Oliver Hart, and George L. Perry (1992). "The Structure and Performance of the Money Management Industry, Brookings Papers on Economic Activity: Microeconomics, pp. 339-91.

Lusardi, Annamaria and Olivia S. Mitchell (2007). "Baby Boomer Retirement Security: The Roles of Planning, Financial Literacy, and Housing Wealth”, Journal of Monetary Economics, 54, 205-24.

Metrick, Andrew (1999). "Performance Evaluation with Transactions Data: The Stock Selection of Investment Newsletters”, Journal of Finance, 54, No. 5, 1743-774.

Niessen, Alexandra and Stefan Ruenzi (2008). “Sex Matters: Gender and Mutual Funds”, Working Paper.

Odean, Terrance (1998). “Are Investors Reluctant to Realize their Losses?”, Journal of Finance, Vol. LIII, No. 5, 1775-798.

Odean, Terrance (1999). “Do Investors Trade Too Much?”, American Economic Review, 89, No. 5, 1279-298.

Ottaviani, Marco (2000). 'The Economics of Advice”, Working Paper. 
Shapira, Zur and Itzhak Venezia (2001). "Patterns of Behavior of Professionally Managed and Independent Investors”, Journal of Banking and Finance, 25, No. 8, 1573-587.

Stulz, Renè M., and Hamid Mehran (2007). “The Economics of Conflicts of Interest in Financial Institutions, Journal of Financial Economics, 85, No. 2, 267-96.

Womack, Kent L. (1996). "Do Brokerage Analysts. Recommendations Have Investment Value?, Journal of Finance, 51, No. 1, 137-67.

Zhu, Ning (2002). “The Local Bias of Individual Investors”, Yale ICF Working Paper No. 02-30. 


\section{Figure 1}

The Distributions of Monthly Returns

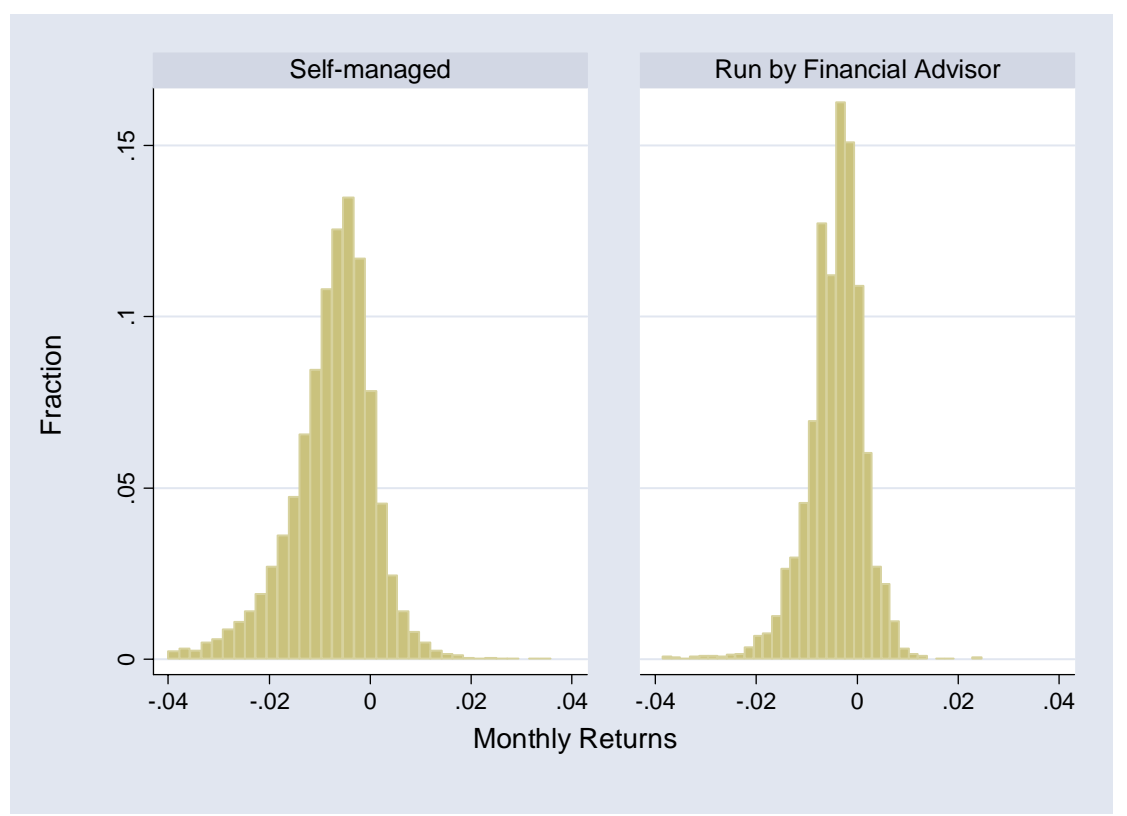

Figure 2

The Distribution of Jensen's Alpha

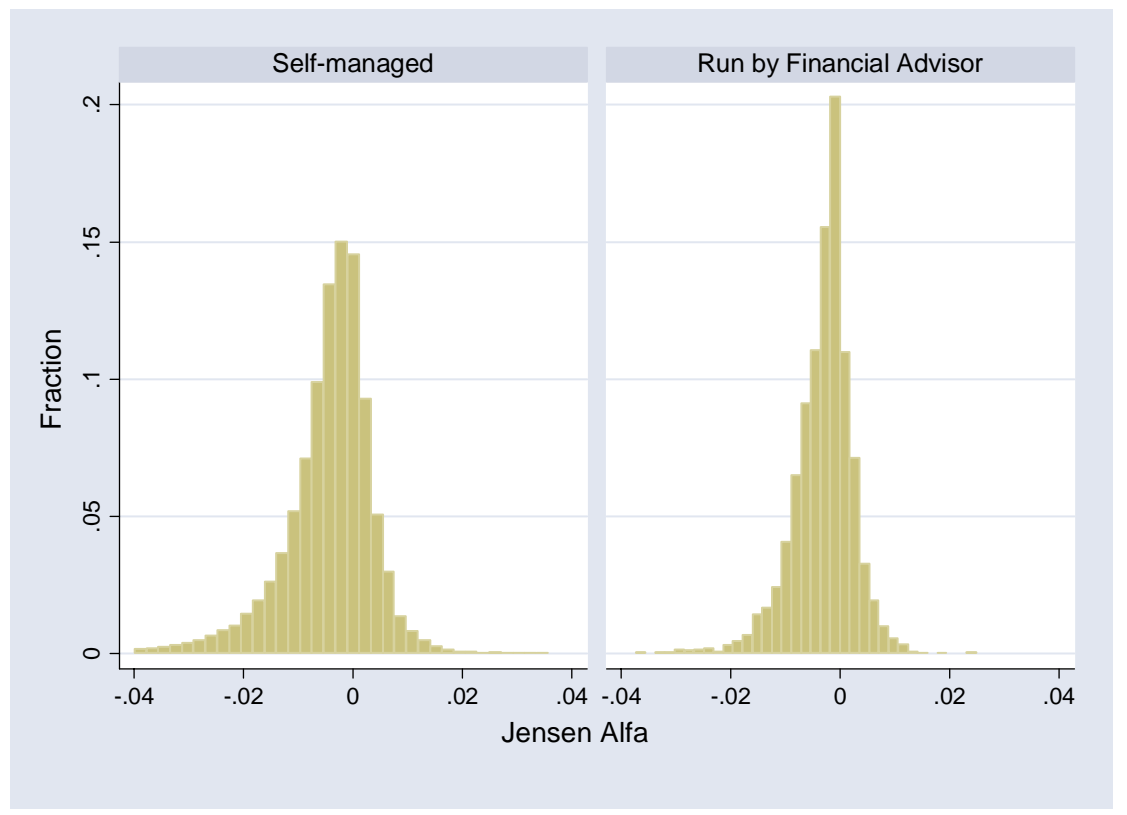




\section{Figure 3}

The Distributions of the Variance of Portfolio Returns

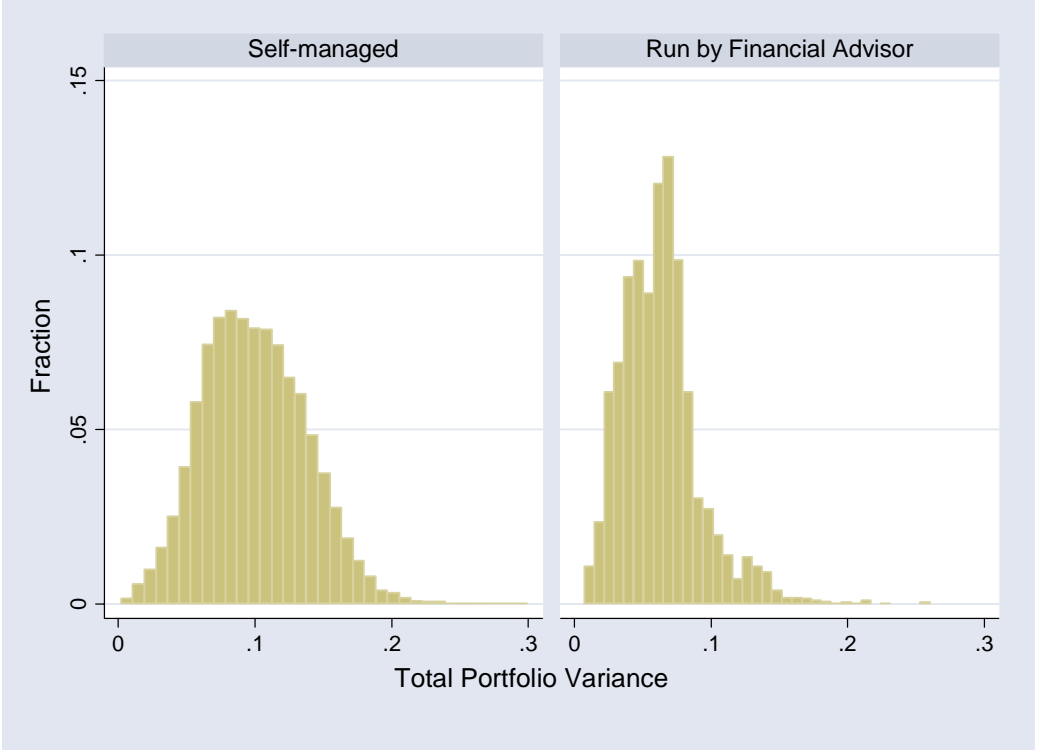

Figure 4

The Distributions of Beta

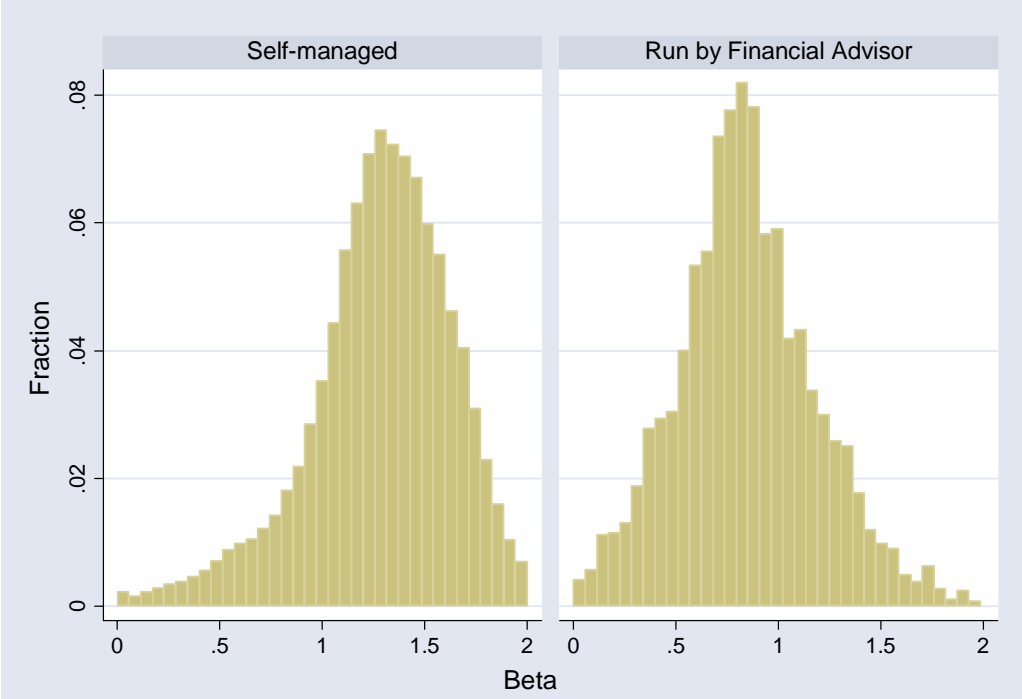




\section{Figure 5}

The Distributions of Unsystematic Risk

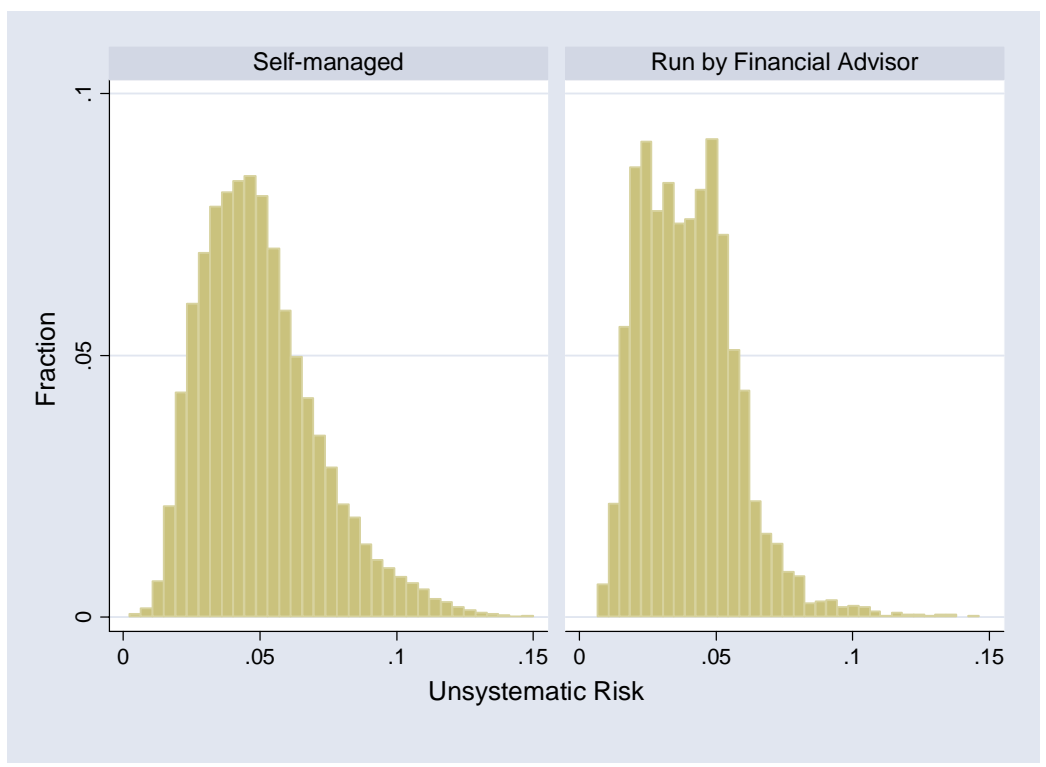

Figure 6

The Distributions of the Probability of Low Returns

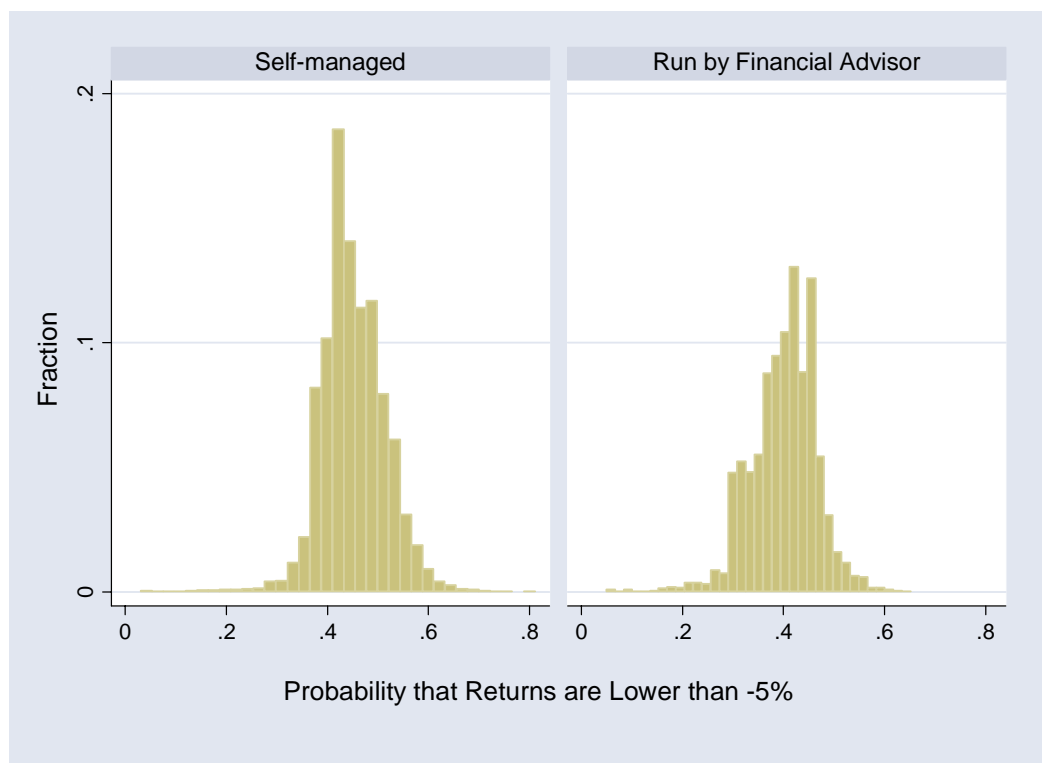




\section{Figure 7}

The Distribution of Number of Trades

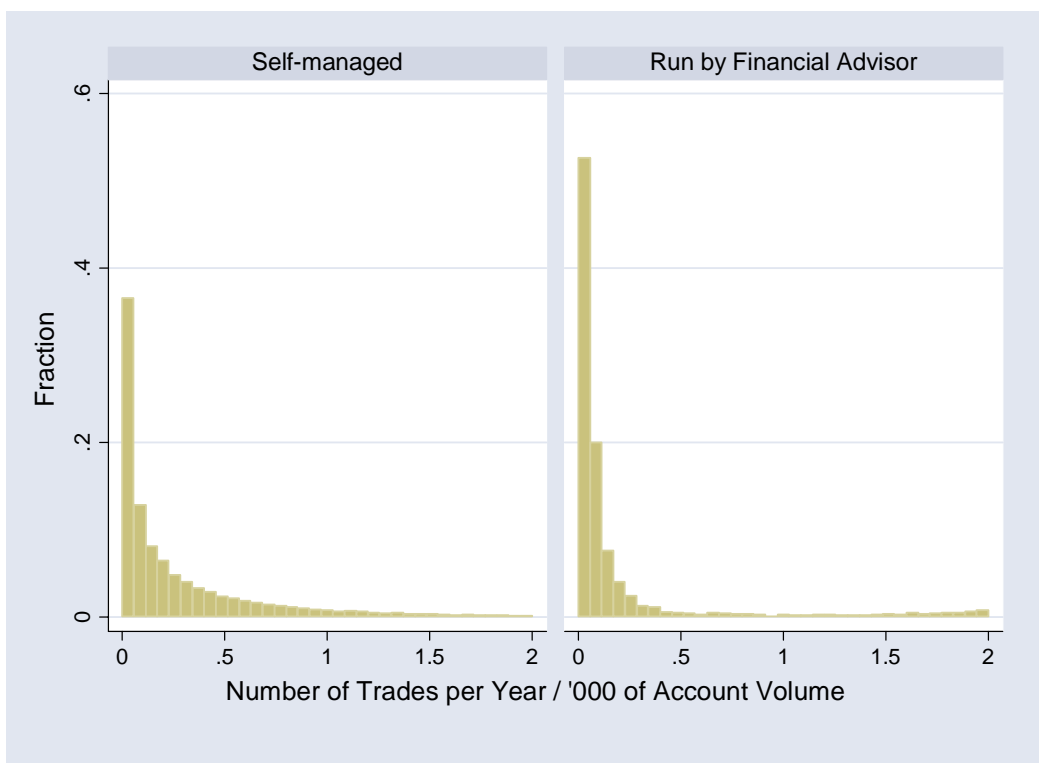

Figure 8

The Distribution of Turnover

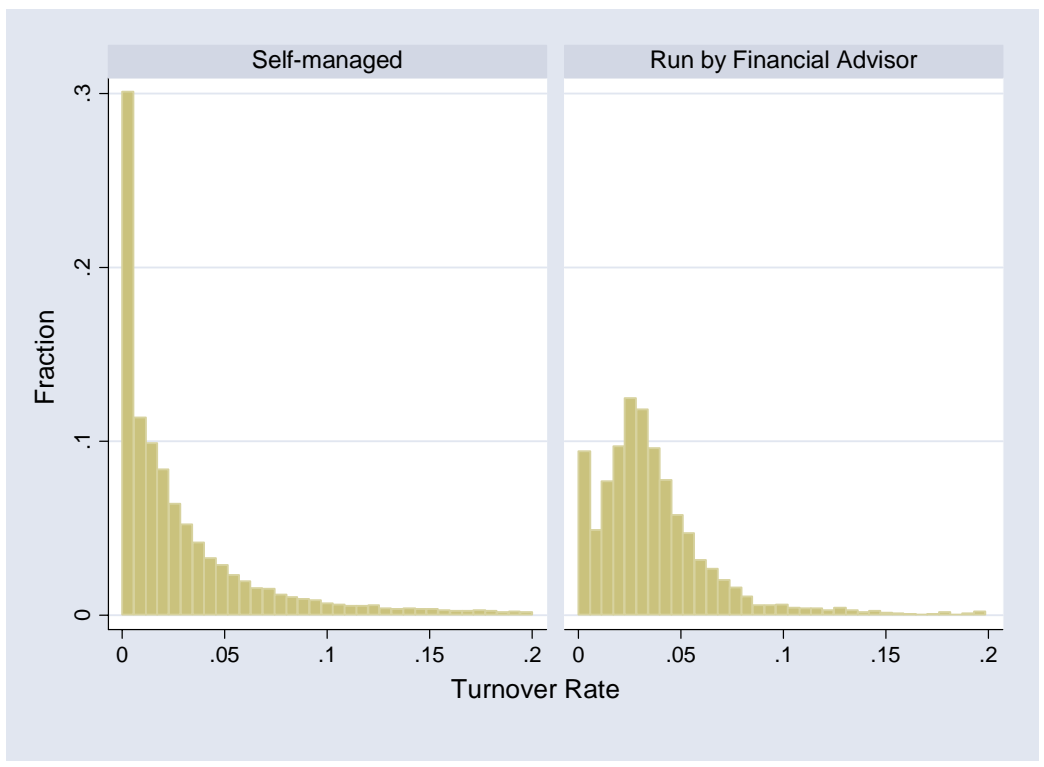




\section{Figure 9}

The Distribution of Portfolio Diversification

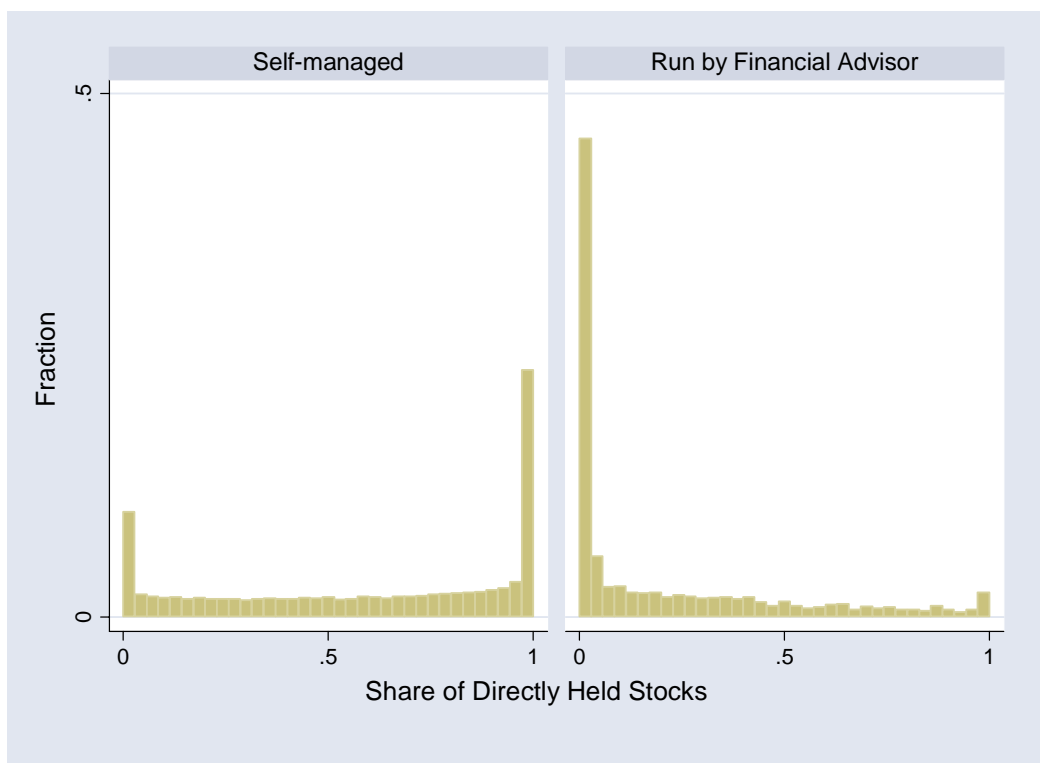


Table 1

Descriptive statistics

\begin{tabular}{|c|c|c|c|c|c|}
\hline & \multicolumn{3}{|c|}{ Sample mean } & \multirow{2}{*}{$\begin{array}{c}\text { Median } \\
\text { All } \\
\text { accounts }\end{array}$} & \multirow{2}{*}{$\begin{array}{c}\text { Standard } \\
\text { deviation } \\
\text { All } \\
\text { accounts }\end{array}$} \\
\hline & $\begin{array}{c}\text { Self-managed } \\
\text { account }\end{array}$ & $\begin{array}{c}\text { Run by } \\
\text { financial } \\
\text { advisor }\end{array}$ & $\begin{array}{c}\text { All } \\
\text { accounts }\end{array}$ & & \\
\hline \multicolumn{6}{|l|}{ Dependent variables } \\
\hline Monthly rates of return & -0.008 & -0.004 & -0.007 & -0.006 & 0.009 \\
\hline Log monthly gross returns & -0.008 & -0.004 & -0.007 & -0.006 & 0.009 \\
\hline Jensen's Alpha (excess log returns) & -0.005 & -0.003 & -0.004 & -0.003 & 0.009 \\
\hline Variance of portfolio returns & 0.100 & 0.063 & 0.095 & 0.092 & 0.039 \\
\hline Unsystematic risk & 0.050 & 0.040 & 0.049 & 0.046 & 0.021 \\
\hline Beta & 1.289 & 0.843 & 1.233 & 1.272 & 0.387 \\
\hline Probability return $<-5 \%$ & 0.451 & 0.401 & 0.445 & 0.446 & 0.065 \\
\hline Probability return $<0$ & 0.479 & 0.447 & 0.475 & 0.469 & 0.058 \\
\hline N. of trades / '000 account volume & 0.444 & 0.319 & 0.428 & 0.113 & 1.265 \\
\hline Turnover rate & 0.041 & 0.089 & 0.047 & 0.020 & 0.086 \\
\hline Share of directly held stocks & 0.588 & 0.211 & 0.540 & 0.575 & 0.373 \\
\hline \multicolumn{6}{|l|}{ Control variables } \\
\hline Male & 0.793 & 0.674 & 0.778 & 1.000 & 0.416 \\
\hline Married & 0.480 & 0.464 & 0.478 & 0.000 & 0.500 \\
\hline Employed & 0.865 & 0.834 & 0.861 & 1.000 & 0.346 \\
\hline Self-employed & 0.129 & 0.158 & 0.132 & 0.000 & 0.339 \\
\hline Experience & 7.335 & 9.161 & 7.562 & 3.900 & 6.211 \\
\hline $18 \leq$ Age $\leq 30$ & 0.047 & 0.042 & 0.046 & 0.000 & 0.210 \\
\hline $30<$ Age $\leq 40$ & 0.260 & 0.119 & 0.242 & 0.000 & 0.428 \\
\hline $40<$ Age $\leq 50$ & 0.344 & 0.269 & 0.335 & 0.000 & 0.472 \\
\hline $50<$ Age $\leq 60$ & 0.195 & 0.229 & 0.199 & 0.000 & 0.399 \\
\hline Age $>60$ & 0.154 & 0.341 & 0.178 & 0.000 & 0.382 \\
\hline \multicolumn{6}{|l|}{ Instrumental variables } \\
\hline Log Account Volume in 2001 & 9.854 & 11.119 & 10.015 & 9.897 & 1.344 \\
\hline Bank Branches, per Capita & 0.186 & 0.176 & 0.185 & 0.079 & 0.186 \\
\hline Log Income in Region, per Capita & 9.826 & 9.835 & 9.827 & 9.824 & 0.136 \\
\hline Log Income in Region & 15.455 & 15.361 & 15.443 & 15.339 & 0.869 \\
\hline Voter Participation & 0.784 & 0.786 & 0.784 & 0.785 & 0.029 \\
\hline Pop. with college degree (fraction) & 0.258 & 0.248 & 0.256 & 0.247 & 0.080 \\
\hline Observations & 25,475 & 3,701 & 29,176 & 29,176 & 29,176 \\
\hline
\end{tabular}


Table 2

The determinants of having the account run by a financial advisor. Probit estimates

\begin{tabular}{l|ccc}
\hline & $\mathbf{( 1 )}$ & $\mathbf{( 2 )}$ & $\mathbf{( 3 )}$ \\
\hline Male & $-0.060^{* * *}$ & $-0.066^{* * *}$ & $-0.069^{* * *}$ \\
Married & $(12.77)$ & $(14.81)$ & $(15.67)$ \\
& $-0.018^{* * *}$ & $-0.015^{* * *}$ & $-0.019^{* * *}$ \\
Employee & $(4.74)$ & $(4.17)$ & $(5.02)$ \\
& 0.035 & $0.038^{*}$ & $0.038^{* *}$ \\
Self-employed & $(1.62)$ & $(1.94)$ & $(1.96)$ \\
& $0.064^{* *}$ & $0.046^{*}$ & $0.048^{*}$ \\
Experience & $(2.31)$ & $(1.83)$ & $(1.92)$ \\
& $0.003^{* * *}$ & 0.000 & 0.001 \\
$30<$ Age $<=40$ & $(10.80)$ & $(1.17)$ & $(1.44)$ \\
& $-0.035^{* * *}$ & $-0.035^{* * *}$ & $-0.033^{* * *}$ \\
$40<$ Age $<=50$ & $(3.51)$ & $(3.88)$ & $(3.51)$ \\
& 0.014 & -0.012 & -0.010 \\
$50<$ Age $<=60$ & $(1.34)$ & $(1.31)$ & $(1.01)$ \\
Age $>$ 60 & $0.057 * * *$ & 0.003 & 0.004 \\
& $(4.97)$ & $(0.34)$ & $(0.39)$ \\
Log Account Volume in 2001 & $0.143^{* * *}$ & $0.037 * * *$ & $0.039^{* * *}$ \\
Bank Branches per Capita & $(11.12)$ & $(3.49)$ & $(3.36)$ \\
& & $0.059^{* * *}$ & $0.060^{* * *}$ \\
Log Income in Region & & $(41.51)$ & $(38.76)$ \\
Voter Participation & & & -0.005 \\
& & & $(0.27)$ \\
Population with college degree (fraction) & & $-0.009^{* *}$ \\
Observations & & & $(2.27)$ \\
& & & 0.049 \\
& & & $(0.40)$ \\
& & & $-0.197 * * *$ \\
& & & $(3.95)$ \\
& & 28631 & 28264 \\
\hline
\end{tabular}

Note. The table reports probit estimates for the probability of having a financial advisor. We report marginal effects rather the original probit coefficients. Asymptotic standard errors corrected for clustering at the zip code level are reported in parenthesis. 
Table 3

The determinants of log returns and Jensen's Alpha. Instrumental variable estimates

\begin{tabular}{|c|c|c|c|c|}
\hline & \multicolumn{2}{|c|}{ Log returns } & \multicolumn{2}{|c|}{ Alfa } \\
\hline & (1) & (2) & (3) & (4) \\
\hline Financial Advisor & $\begin{array}{c}-0.020 * * * \\
(4.39)\end{array}$ & $\begin{array}{c}-0.019 * * * \\
(5.35)\end{array}$ & $\begin{array}{c}-0.019 * * * \\
(4.57)\end{array}$ & $\begin{array}{c}-0.018 * * * \\
(5.58)\end{array}$ \\
\hline Male & $\begin{array}{c}-0.003 * * * \\
(8.04)\end{array}$ & $\begin{array}{c}-0.003^{* * *} \\
(9.70)\end{array}$ & $\begin{array}{c}-0.002 * * * \\
(7.81)\end{array}$ & $\begin{array}{c}-0.002 * * * \\
(9.29)\end{array}$ \\
\hline Married & $\begin{array}{l}-0.000 \\
(0.72)\end{array}$ & $\begin{array}{l}-0.000 \\
(0.61)\end{array}$ & $\begin{array}{l}-0.000 \\
(0.55)\end{array}$ & $\begin{array}{l}-0.000 \\
(0.49)\end{array}$ \\
\hline Employee & $\begin{array}{l}-0.001 \\
(0.78)\end{array}$ & $\begin{array}{l}-0.000 \\
(0.66)\end{array}$ & $\begin{array}{l}-0.001 \\
(0.82)\end{array}$ & $\begin{array}{l}-0.000 \\
(0.66)\end{array}$ \\
\hline Self-employed & $\begin{array}{l}-0.001 \\
(0.66)\end{array}$ & $\begin{array}{l}-0.001 \\
(1.45)\end{array}$ & $\begin{array}{l}-0.001 \\
(0.75)\end{array}$ & $\begin{array}{l}-0.001 \\
(1.47)\end{array}$ \\
\hline Experience & $\begin{array}{c}0.0002^{* * *} \\
(9.89)\end{array}$ & $\begin{array}{c}0.0001^{* * *} \\
(9.23)\end{array}$ & $\begin{array}{c}0.0002^{* * *} \\
(9.59)\end{array}$ & $\begin{array}{c}0.0001^{* * *} \\
(8.74)\end{array}$ \\
\hline $30<$ Age $<=40$ & $\begin{array}{c}-0.001 * * \\
(2.28)\end{array}$ & $\begin{array}{c}-0.001 * * * \\
(3.12)\end{array}$ & $\begin{array}{c}-0.001 * \\
(1.69)\end{array}$ & $\begin{array}{c}-0.001^{* *} \\
(2.46)\end{array}$ \\
\hline $40<$ Age $<=50$ & $\begin{array}{l}-0.000 \\
(0.95)\end{array}$ & $\begin{array}{c}-0.001 * * * \\
(3.92)\end{array}$ & $\begin{array}{l}-0.000 \\
(0.51)\end{array}$ & $\begin{array}{c}-0.001^{* * *} \\
(3.29)\end{array}$ \\
\hline $50<$ Age $<=60$ & $\begin{array}{c}0.001^{* *} \\
(2.25)\end{array}$ & $\begin{array}{c}-0.001^{* *} \\
(1.99)\end{array}$ & $\begin{array}{c}0.001^{* *} \\
(2.40)\end{array}$ & $\begin{array}{l}-0.001 \\
(1.56)\end{array}$ \\
\hline Age $>60$ & $\begin{array}{c}0.004^{* * *} \\
(5.61)\end{array}$ & $\begin{array}{c}0.001^{* * *} \\
(3.23)\end{array}$ & $\begin{array}{c}0.004^{* * *} \\
(5.28)\end{array}$ & $\begin{array}{c}0.001 * * * \\
(2.83)\end{array}$ \\
\hline Log Account Volume in 2001 & & $\begin{array}{c}0.002^{* * *} \\
(8.45)\end{array}$ & & $\begin{array}{c}0.002^{* * *} \\
(8.16)\end{array}$ \\
\hline Constant & $\begin{array}{c}-0.005^{* * *} \\
(5.13)\end{array}$ & $\begin{array}{c}-0.024^{* * *} \\
(11.19)\end{array}$ & $\begin{array}{c}-0.002 * * \\
(2.19)\end{array}$ & $\begin{array}{c}-0.019 * * * \\
(9.63)\end{array}$ \\
\hline Observations & 28264 & 28264 & 28264 & 28264 \\
\hline
\end{tabular}

Note. The table reports instrumental variables estimates using the following instruments for financial advice at the zip code level: bank branches per capita, log income in the zip code of residence, voter participation, and fraction of the population with college degree. Asymptotic t-statistics corrected for clustering at the zip code level are reported in parenthesis. 


\section{Table 4}

\section{The determinants of portfolio variance, Beta and unsystematic risk. Instrumental variable estimates}

\begin{tabular}{|c|c|c|c|c|c|c|}
\hline & \multicolumn{2}{|c|}{ Portfolio Variance } & \multicolumn{2}{|c|}{ Beta } & \multicolumn{2}{|c|}{ Unsystematic Risk } \\
\hline & (1) & (2) & (3) & (4) & (5) & (6) \\
\hline Financial Advisor & $\begin{array}{c}0.060 * * * \\
(3.20)\end{array}$ & $\begin{array}{c}0.049 * * * \\
(3.61)\end{array}$ & $\begin{array}{c}0.440 * * \\
(2.45)\end{array}$ & $\begin{array}{c}0.361^{* * *} \\
(2.72)\end{array}$ & $\begin{array}{c}0.034 * * * \\
(3.71)\end{array}$ & $\begin{array}{c}0.028 * * * \\
(4.15)\end{array}$ \\
\hline Male & $\begin{array}{c}0.014^{* * *} \\
(10.12)\end{array}$ & $\begin{array}{c}0.014^{* * *} \\
(12.41)\end{array}$ & $\begin{array}{c}0.105^{* * * *} \\
(7.97)\end{array}$ & $\begin{array}{c}0.107 * * * \\
(9.61)\end{array}$ & $\begin{array}{c}0.007 * * * \\
(11.17)\end{array}$ & $\begin{array}{c}0.008 * * * \\
(13.46)\end{array}$ \\
\hline Married & $\begin{array}{c}-0.001^{* *} \\
(1.98)\end{array}$ & $\begin{array}{c}-0.002^{* * *} \\
(2.70)\end{array}$ & $\begin{array}{l}0.003 \\
(0.40)\end{array}$ & $\begin{array}{l}0.001 \\
(0.18)\end{array}$ & $\begin{array}{c}-0.001^{* * *} \\
(3.32)\end{array}$ & $\begin{array}{c}-0.001 * * * \\
(4.25)\end{array}$ \\
\hline Employee & $\begin{array}{l}0.002 \\
(0.68)\end{array}$ & $\begin{array}{l}0.002 \\
(0.61)\end{array}$ & $\begin{array}{l}0.021 \\
(0.58)\end{array}$ & $\begin{array}{l}0.017 \\
(0.50)\end{array}$ & $\begin{array}{l}0.001 \\
(0.49)\end{array}$ & $\begin{array}{l}0.001 \\
(0.38)\end{array}$ \\
\hline Self-employed & $\begin{array}{l}0.003 \\
(0.95)\end{array}$ & $\begin{array}{c}0.006^{*} \\
(1.89)\end{array}$ & $\begin{array}{l}0.019 \\
(0.48)\end{array}$ & $\begin{array}{l}0.038 \\
(1.08)\end{array}$ & $\begin{array}{l}0.002 \\
(1.18)\end{array}$ & $\begin{array}{c}0.004^{* *} \\
(2.15)\end{array}$ \\
\hline Experience & $\begin{array}{c}-0.001 * * * \\
(11.52)\end{array}$ & $\begin{array}{c}-0.001^{* * *} \\
(11.41)\end{array}$ & $\begin{array}{c}-0.009 * * * \\
(10.22)\end{array}$ & $\begin{array}{c}-0.005^{* * *} \\
(10.17)\end{array}$ & $\begin{array}{c}-0.000 * * * \\
(10.70)\end{array}$ & $\begin{array}{c}-0.000 * * * \\
(8.76)\end{array}$ \\
\hline $30<$ Age $<=40$ & $\begin{array}{c}0.006^{* * *} \\
(4.09)\end{array}$ & $\begin{array}{c}0.007 * * * \\
(5.19)\end{array}$ & $\begin{array}{c}0.069 * * * \\
(4.74)\end{array}$ & $\begin{array}{c}0.077 * * * \\
(5.63)\end{array}$ & $\begin{array}{c}0.002 * * \\
(2.44)\end{array}$ & $\begin{array}{c}0.003 * * * \\
(3.33)\end{array}$ \\
\hline $40<$ Age $<=50$ & $\begin{array}{c}0.003^{* *} \\
(2.24)\end{array}$ & $\begin{array}{c}0.008 * * * \\
(5.84)\end{array}$ & $\begin{array}{c}0.037 * * * \\
(2.66)\end{array}$ & $\begin{array}{c}0.075^{* * *} \\
(5.62)\end{array}$ & $\begin{array}{c}0.001 \\
(0.86)\end{array}$ & $\begin{array}{c}0.003 * * * \\
(4.29)\end{array}$ \\
\hline $50<$ Age $<=60$ & $\begin{array}{r}-0.003 \\
(1.49)\end{array}$ & $\begin{array}{c}0.005^{* * *} \\
(3.76)\end{array}$ & $\begin{array}{c}-0.014 \\
(0.81)\end{array}$ & $\begin{array}{c}0.051^{* * *} \\
(3.67)\end{array}$ & $\begin{array}{c}-0.002^{* *} \\
(2.26)\end{array}$ & $\begin{array}{c}0.002 * * * \\
(2.89)\end{array}$ \\
\hline $\begin{array}{l}\text { Age }>60 \\
\text { Log Account Volume in } 2001\end{array}$ & $\begin{array}{c}-0.018 * * * \\
(5.92)\end{array}$ & $\begin{array}{c}-0.005^{* * *} \\
(2.89) \\
-0.009 * * * \\
(9.55)\end{array}$ & $\begin{array}{c}-0.166^{* * *} \\
(5.69)\end{array}$ & $\begin{array}{c}-0.058 * * * \\
(3.63) \\
-0.076 * * * \\
(7.94)\end{array}$ & $\begin{array}{c}-0.009 * * * \\
(5.62)\end{array}$ & $\begin{array}{c}-0.001 \\
(1.58) \\
-0.005^{* * *} \\
(10.45)\end{array}$ \\
\hline Constant & $\begin{array}{c}0.084 * * * \\
(22.13)\end{array}$ & $\begin{array}{c}0.170 * * * \\
(20.15)\end{array}$ & $\begin{array}{c}1.144^{* * *} \\
(28.22)\end{array}$ & $\begin{array}{c}1.843^{* * *} \\
(21.93)\end{array}$ & $\begin{array}{c}0.043 * * * \\
(21.62)\end{array}$ & $\begin{array}{c}0.090 * * * \\
(21.12)\end{array}$ \\
\hline Observations & 28264 & 28264 & 28264 & 28264 & 28264 & 28264 \\
\hline
\end{tabular}

Note. The table reports instrumental variables estimates using the following instruments for financial advice at the zip code level: bank branches per capita, log income in the zip code of residence, voter participation, and fraction of the population with college degree. Asymptotic t-statistics corrected for clustering at the zip code level are reported in parenthesis. 
Table 5

The determinants of the probability of low returns. Instrumental variable estimates

\begin{tabular}{|c|c|c|c|c|}
\hline & \multicolumn{2}{|c|}{ Probability of return less than $-5 \%$} & \multicolumn{2}{|c|}{ Probability of return less than 0} \\
\hline & (1) & (2) & (3) & (4) \\
\hline Financial Advisor & $\begin{array}{c}0.094 * * * \\
(3.29)\end{array}$ & $\begin{array}{c}0.088 * * * \\
(4.03)\end{array}$ & $\begin{array}{c}0.071 * * * \\
(3.15)\end{array}$ & $\begin{array}{c}0.068 * * * \\
(3.76)\end{array}$ \\
\hline Male & $\begin{array}{c}0.021 * * * \\
(9.81)\end{array}$ & $\begin{array}{c}0.022 * * * \\
(11.67)\end{array}$ & $\begin{array}{c}0.014 * * * \\
(8.62)\end{array}$ & $\begin{array}{c}0.015 * * * \\
(9.90)\end{array}$ \\
\hline Married & $\begin{array}{l}-0.001 \\
(0.98)\end{array}$ & $\begin{array}{l}-0.001 \\
(1.21)\end{array}$ & $\begin{array}{c}-0.001 \\
(1.21)\end{array}$ & $\begin{array}{l}-0.001 \\
(1.38)\end{array}$ \\
\hline Employee & $\begin{array}{c}0.015^{* *} \\
(2.33)\end{array}$ & $\begin{array}{c}0.014^{* *} \\
(2.31)\end{array}$ & $\begin{array}{c}0.014^{* * *} \\
(2.67)\end{array}$ & $\begin{array}{c}0.013 * * * \\
(2.67)\end{array}$ \\
\hline Self-employed & $\begin{array}{c}0.018 * * * \\
(2.69)\end{array}$ & $\begin{array}{c}0.021^{* * *} \\
(3.46)\end{array}$ & $\begin{array}{c}0.018 * * * \\
(3.34)\end{array}$ & $\begin{array}{c}0.020 * * * \\
(4.07)\end{array}$ \\
\hline Experience & $\begin{array}{c}-0.002 * * * \\
(11.05)\end{array}$ & $\begin{array}{c}-0.001^{* * *} \\
(10.50)\end{array}$ & $\begin{array}{c}-0.001 * * * \\
(11.46)\end{array}$ & $\begin{array}{c}-0.001^{* * *} \\
(11.48)\end{array}$ \\
\hline $30<$ Age $<=40$ & $\begin{array}{c}0.007 * * * \\
(2.75)\end{array}$ & $\begin{array}{c}0.009 * * * \\
(3.56)\end{array}$ & $\begin{array}{l}0.003 \\
(1.49)\end{array}$ & $\begin{array}{c}0.004 * * \\
(2.14)\end{array}$ \\
\hline $40<$ Age $<=50$ & $\begin{array}{c}0.005^{* *} \\
(2.09)\end{array}$ & $\begin{array}{c}0.012^{* * *} \\
(4.92)\end{array}$ & $\begin{array}{l}0.002 \\
(0.96)\end{array}$ & $\begin{array}{c}0.007 * * * \\
(3.32)\end{array}$ \\
\hline $50<$ Age $<=60$ & $\begin{array}{l}-0.003 \\
(0.97)\end{array}$ & $\begin{array}{c}0.008^{* * *} \\
(3.29)\end{array}$ & $\begin{array}{l}-0.004 \\
(1.42)\end{array}$ & $\begin{array}{c}0.005^{* *} \\
(2.11)\end{array}$ \\
\hline Age $>60$ & $\begin{array}{c}-0.025 * * * \\
(5.22)\end{array}$ & $\begin{array}{c}-0.007 * * \\
(2.39)\end{array}$ & $\begin{array}{c}-0.018^{* * *} \\
(4.76)\end{array}$ & $\begin{array}{c}-0.005^{* *} \\
(2.21)\end{array}$ \\
\hline Log Account Volume in 2001 & & $\begin{array}{c}-0.014^{* * *} \\
(8.77)\end{array}$ & & $\begin{array}{c}-0.010^{* * * *} \\
(7.70)\end{array}$ \\
\hline Constant & $\begin{array}{c}0.416^{* * *} \\
(61.78)\end{array}$ & $\begin{array}{c}0.541^{* * *} \\
(38.12)\end{array}$ & $\begin{array}{c}0.454 * * * \\
(82.96)\end{array}$ & $\begin{array}{c}0.544^{* * *} \\
(47.07)\end{array}$ \\
\hline Observations & 28264 & 28264 & 28264 & 28264 \\
\hline
\end{tabular}

Note. The table reports instrumental variables estimates using the following instruments for financial advice at the zip code level: bank branches per capita, log income in the zip code of residence, voter participation, and fraction of the population with college degree. Asymptotic t-statistics corrected for clustering at the zip code level are reported in parenthesis. 
Table 6

The determinants of trading frequency, turnover and diversification. Instrumental variable estimates

\begin{tabular}{|c|c|c|c|c|c|c|}
\hline & \multicolumn{2}{|c|}{$\begin{array}{c}\text { Number of Trades per ' } 00( \\
\text { Account Volume }\end{array}$} & \multicolumn{2}{|c|}{ Turnover } & \multicolumn{2}{|c|}{$\begin{array}{c}\text { Share of Directly Held } \\
\text { Stocks }\end{array}$} \\
\hline & (1) & (2) & (3) & (4) & (5) & (6) \\
\hline Financial Advisor & $\begin{array}{c}1.396 * * * \\
(2.69)\end{array}$ & $\begin{array}{c}1.306^{* * *} \\
(3.07)\end{array}$ & $\begin{array}{c}0.304 * * * \\
(6.16)\end{array}$ & $\begin{array}{l}0.280 * * * \\
(7.11)\end{array}$ & $\begin{array}{l}-0.235 \\
(1.46)\end{array}$ & $\begin{array}{l}-0.192 \\
(1.51)\end{array}$ \\
\hline Male & $\begin{array}{c}0.254 * * * \\
(7.61)\end{array}$ & $\begin{array}{c}0.269 * * * \\
(8.98)\end{array}$ & $\begin{array}{c}0.032 * * * \\
(9.08)\end{array}$ & $\begin{array}{c}0.032 * * * \\
(10.32)\end{array}$ & $\begin{array}{l}0.101^{* * *} \\
(8.80)\end{array}$ & $\begin{array}{l}0.104 * * * \\
(9.97)\end{array}$ \\
\hline Married & $\begin{array}{l}0.033^{*} \\
(1.88)\end{array}$ & $\begin{array}{l}0.031^{*} \\
(1.90)\end{array}$ & $\begin{array}{c}0.006 * * * \\
(3.40)\end{array}$ & $\begin{array}{l}0.006^{* * *} \\
(3.50)\end{array}$ & $\begin{array}{l}-0.017^{* * * *} \\
(2.89)\end{array}$ & $\begin{array}{c}-0.016^{* * *} \\
(2.90)\end{array}$ \\
\hline Employee & $\begin{array}{l}-0.004 \\
(0.07)\end{array}$ & $\begin{array}{l}-0.025 \\
(0.41)\end{array}$ & $\begin{array}{l}-0.009 \\
(0.99)\end{array}$ & $\begin{array}{l}-0.010 \\
(1.23)\end{array}$ & $\begin{array}{l}0.080 * * \\
(2.53)\end{array}$ & $\begin{array}{c}0.077^{* *} \\
(2.47)\end{array}$ \\
\hline Self-employed & $\begin{array}{l}-0.140 * \\
(1.90)\end{array}$ & $\begin{array}{l}-0.090 \\
(1.43)\end{array}$ & $\begin{array}{c}-0.020^{* *} \\
(2.01)\end{array}$ & $\begin{array}{c}-0.015 * \\
(1.77)\end{array}$ & $\begin{array}{l}0.121 * * * \\
(3.67)\end{array}$ & $\begin{array}{l}0.117 * * * \\
(3.67)\end{array}$ \\
\hline Experience & $\begin{array}{l}-0.017 * * * \\
(8.78)\end{array}$ & $\begin{array}{l}-0.006^{* * *} \\
(5.40)\end{array}$ & $\begin{array}{l}-0.002^{* * *} \\
(8.41)\end{array}$ & $\begin{array}{l}-0.001^{* * * *} \\
(7.59)\end{array}$ & $\begin{array}{c}-0.007 * * * \\
(10.41)\end{array}$ & $\begin{array}{c}-0.008^{* * *} \\
(17.45)\end{array}$ \\
\hline $30<$ Age $<=40$ & $\begin{array}{l}0.034 \\
(0.78)\end{array}$ & $\begin{array}{l}0.063 \\
(1.54)\end{array}$ & $\begin{array}{c}0.010 * * * \\
(2.72)\end{array}$ & $\begin{array}{c}0.011 * * * \\
(3.46)\end{array}$ & $\begin{array}{l}0.012 \\
(0.90)\end{array}$ & $\begin{array}{l}0.013 \\
(0.98)\end{array}$ \\
\hline $40<$ Age $<=50$ & $\begin{array}{l}-0.025 \\
(0.60)\end{array}$ & $\begin{array}{c}0.091^{* *} \\
(2.34)\end{array}$ & $\begin{array}{l}0.003 \\
(0.82)\end{array}$ & $\begin{array}{l}0.012 * * * \\
(3.60)\end{array}$ & $\begin{array}{l}0.020 \\
(1.54)\end{array}$ & $\begin{array}{l}0.019 \\
(1.45)\end{array}$ \\
\hline $50<$ Age $<=60$ & $\begin{array}{c}-0.113^{* *} \\
(2.34)\end{array}$ & $\begin{array}{c}0.081^{* *} \\
(2.06)\end{array}$ & $\begin{array}{l}-0.004 \\
(0.90)\end{array}$ & $\begin{array}{c}0.012 * * * \\
(3.38)\end{array}$ & $\begin{array}{c}0.036^{* *} \\
(2.36)\end{array}$ & $\begin{array}{c}0.034^{* *} \\
(2.54)\end{array}$ \\
\hline Age $>60$ & $\begin{array}{c}-0.341 * * * \\
(3.83)\end{array}$ & $\begin{array}{l}-0.024 \\
(0.46)\end{array}$ & $\begin{array}{c}-0.034^{* * *} \\
(4.29)\end{array}$ & $\begin{array}{l}-0.008^{*} \\
(1.84)\end{array}$ & $\begin{array}{l}0.030 \\
(1.17)\end{array}$ & $\begin{array}{l}0.024 \\
(1.57)\end{array}$ \\
\hline Log Account Volume in 2001 & & $\begin{array}{c}-0.240^{* * *} \\
(8.54)\end{array}$ & & $\begin{array}{c}-0.018^{* * *} \\
(6.57)\end{array}$ & & $\begin{array}{l}-0.000 \\
(0.01)\end{array}$ \\
\hline Constant & $\begin{array}{c}0.274^{* * * *} \\
(3.54)\end{array}$ & $\begin{array}{c}2.461 * * * \\
(10.54)\end{array}$ & $\begin{array}{l}0.010 \\
(1.01)\end{array}$ & $\begin{array}{c}0.176^{* * *} \\
(7.38)\end{array}$ & $\begin{array}{c}0.394 * * * \\
(11.27)\end{array}$ & $\begin{array}{c}0.391^{* * *} \\
(5.00)\end{array}$ \\
\hline Observations & 28264 & 28264 & 28264 & 28264 & 28264 & 28264 \\
\hline
\end{tabular}

Note. The table reports instrumental variables estimates for number of trades and turnover, and instrumental variable tobit estimates for the share of directly help stocks using the following instruments for financial advice at the zip code level: bank branches per capita, log income in the zip code of residence, voter participation, and fraction of the population with college degree. Asymptotic t-statistics corrected for clustering at the zip code level are reported in parenthesis. 


\section{Table A1}

\section{The determinants of log returns, Jensen's Alpha, Portfolio variance and Beta. OLS estimates}

\begin{tabular}{|c|c|c|c|c|c|}
\hline & Log returns & $\overline{\text { Alfa }}$ & $\begin{array}{l}\text { Portfolio } \\
\text { variance }\end{array}$ & Beta & $\begin{array}{l}\text { Unsystematic } \\
\text { risk }\end{array}$ \\
\hline Financial Advisor & $\begin{array}{c}0.003 * * * \\
(22.23)\end{array}$ & $\begin{array}{c}0.000 * * * \\
(3.14)\end{array}$ & $\begin{array}{c}-0.029 * * * \\
(39.42)\end{array}$ & $\begin{array}{c}-0.393 * * * \\
(47.94)\end{array}$ & $\begin{array}{c}-0.006 * * * \\
(12.47)\end{array}$ \\
\hline Male & $\begin{array}{c}-0.001 * * * \\
(10.78)\end{array}$ & $\begin{array}{c}-0.001 * * * \\
(10.69)\end{array}$ & $\begin{array}{c}0.008 * * * \\
(16.67)\end{array}$ & $\begin{array}{c}0.056 * * * \\
(10.91)\end{array}$ & $\begin{array}{c}0.005^{* * *} \\
(17.93)\end{array}$ \\
\hline Married & $\begin{array}{c}0.000 * * * \\
(3.52)\end{array}$ & $\begin{array}{c}0.000 * * * \\
(3.17)\end{array}$ & $\begin{array}{c}-0.004 * * * \\
(7.79)\end{array}$ & $\begin{array}{c}-0.017 * * * \\
(3.78)\end{array}$ & $\begin{array}{c}-0.002^{* * *} \\
(8.41)\end{array}$ \\
\hline Employee & $\begin{array}{c}-0.002 * * * \\
(3.23)\end{array}$ & $\begin{array}{c}-0.001^{* * *} \\
(3.14)\end{array}$ & $\begin{array}{c}0.006^{* *} \\
(2.38)\end{array}$ & $\begin{array}{l}0.056^{*} \\
(1.82)\end{array}$ & $\begin{array}{l}0.002^{*} \\
(1.85)\end{array}$ \\
\hline Self-employed & $\begin{array}{c}-0.002^{* * *} \\
(3.83)\end{array}$ & $\begin{array}{c}-0.002 * * * \\
(4.10)\end{array}$ & $\begin{array}{c}0.010 * * * \\
(3.91)\end{array}$ & $\begin{array}{c}0.076^{* *} \\
(2.46)\end{array}$ & $\begin{array}{c}0.005^{* * *} \\
(3.90)\end{array}$ \\
\hline Experience & $\begin{array}{c}0.1 \mathrm{E}-03^{* * *} \\
(16.62)\end{array}$ & $\begin{array}{c}0.1 \mathrm{E}-03^{* * *} \\
(12.09)\end{array}$ & $\begin{array}{c}-0.001^{* * *} \\
(15.05)\end{array}$ & $\begin{array}{c}-0.005^{* * *} \\
(13.43)\end{array}$ & $\begin{array}{c}-0.000^{* * *} \\
(9.89)\end{array}$ \\
\hline $30<$ Age $<=40$ & $\begin{array}{l}-0.000 \\
(0.80)\end{array}$ & $\begin{array}{l}-0.000 \\
(0.52)\end{array}$ & $\begin{array}{c}0.004^{* * *} \\
(3.93)\end{array}$ & $\begin{array}{c}0.048 * * * \\
(4.33)\end{array}$ & $\begin{array}{c}0.001^{* *} \\
(2.11)\end{array}$ \\
\hline $40<$ Age $<=50$ & $\begin{array}{c}-0.001^{* *} \\
(2.11)\end{array}$ & $\begin{array}{c}-0.001^{* *} \\
(2.47)\end{array}$ & $\begin{array}{c}0.006^{* * *} \\
(5.65)\end{array}$ & $\begin{array}{c}0.057 * * * \\
(5.15)\end{array}$ & $\begin{array}{c}0.002^{* * *} \\
(3.86)\end{array}$ \\
\hline $50<$ Age $<=60$ & $\begin{array}{l}-0.000 \\
(0.58)\end{array}$ & $\begin{array}{l}-0.000 \\
(1.63)\end{array}$ & $\begin{array}{c}0.005^{* * *} \\
(4.28)\end{array}$ & $\begin{array}{c}0.047 * * * \\
(4.01)\end{array}$ & $\begin{array}{c}0.002^{* * *} \\
(3.15)\end{array}$ \\
\hline Age $>60$ & $\begin{array}{c}0.001^{* * *} \\
(3.34)\end{array}$ & $\begin{array}{l}0.000 \\
(0.51)\end{array}$ & $\begin{array}{l}-0.001 \\
(0.54)\end{array}$ & $\begin{array}{l}-0.019 \\
(1.59)\end{array}$ & $\begin{array}{l}0.000 \\
(0.55)\end{array}$ \\
\hline Log Account Volume in 2001 & & $\begin{array}{c}0.001^{* * *} \\
(13.21)\end{array}$ & $\begin{array}{c}-0.004 * * * \\
(20.25)\end{array}$ & $\begin{array}{c}-0.023^{* * *} \\
(12.31)\end{array}$ & $\begin{array}{c}-0.003^{* * *} \\
(24.34)\end{array}$ \\
\hline Constant & $\begin{array}{c}-0.006 * * * \\
(12.46)\end{array}$ & $\begin{array}{c}-0.009 * * * \\
(14.60)\end{array}$ & $\begin{array}{c}0.126^{* * *} \\
(40.62)\end{array}$ & $\begin{array}{c}1.421^{* * *} \\
(40.23)\end{array}$ & $\begin{array}{c}0.071^{* * *} \\
(41.03)\end{array}$ \\
\hline Observations & 28631 & 28631 & 28631 & 28631 & 28631 \\
\hline R-squared & 0.03 & 0.02 & 0.15 & 0.17 & 0.08 \\
\hline
\end{tabular}


Table A2

The determinants of probabilities of low returns, trading frequency, turnover, and diversification. OLS estimates

\begin{tabular}{|c|c|c|c|c|c|}
\hline & $\begin{array}{c}\text { Less than } \\
-5 \%\end{array}$ & $\begin{array}{c}\text { Less than } \\
\text { zero }\end{array}$ & $\begin{array}{c}\text { Number of } \\
\text { trades }\end{array}$ & Turnover & $\begin{array}{c}\text { Share of } \\
\text { direct stocks } \\
\text { (Tobit } \\
\text { estimates) }\end{array}$ \\
\hline Financial Advisor & $\begin{array}{c}-0.041 * * * \\
(25.90)\end{array}$ & $\begin{array}{c}-0.026 * * * \\
(20.17)\end{array}$ & $\begin{array}{c}0.113^{* * *} \\
(6.59)\end{array}$ & $\begin{array}{c}0.057 * * * \\
(15.57)\end{array}$ & $\begin{array}{c}-0.485 * * * \\
(42.63)\end{array}$ \\
\hline Male & $\begin{array}{c}0.012 * * * \\
(14.13)\end{array}$ & $\begin{array}{c}0.009 * * * \\
(10.72)\end{array}$ & $\begin{array}{c}0.188^{* * *} * \\
(14.99)\end{array}$ & $\begin{array}{c}0.017 * * * \\
(15.13)\end{array}$ & $\begin{array}{c}0.089 * * * \\
(14.01)\end{array}$ \\
\hline Married & $\begin{array}{c}-0.004^{* * *} \\
(5.37)\end{array}$ & $\begin{array}{c}-0.003^{* * *} \\
(4.71)\end{array}$ & $\begin{array}{l}0.005 \\
(0.33)\end{array}$ & $\begin{array}{l}0.001 \\
(1.00)\end{array}$ & $\begin{array}{c}-0.034 * * * \\
(6.40)\end{array}$ \\
\hline Employee & $\begin{array}{c}0.021^{* * *} \\
(4.38)\end{array}$ & $\begin{array}{c}0.018^{* * *} \\
(4.53)\end{array}$ & $\begin{array}{l}0.040 \\
(0.85)\end{array}$ & $\begin{array}{l}0.002 \\
(0.44)\end{array}$ & $\begin{array}{c}0.104^{* * *} \\
(3.18)\end{array}$ \\
\hline Self-employed & $\begin{array}{c}0.028 * * * \\
(5.76)\end{array}$ & $\begin{array}{c}0.025^{* * *} \\
(6.18)\end{array}$ & $\begin{array}{l}-0.027 \\
(0.55)\end{array}$ & $\begin{array}{l}-0.003 \\
(0.82)\end{array}$ & $\begin{array}{c}0.152^{* * *} \\
(4.55)\end{array}$ \\
\hline Experience & $\begin{array}{c}-0.001^{* * *} \\
(13.78)\end{array}$ & $\begin{array}{c}-0.001 * * * \\
(13.87)\end{array}$ & $\begin{array}{c}-0.006^{* * *} \\
(5.46)\end{array}$ & $\begin{array}{c}-0.001^{* * *} \\
(10.78)\end{array}$ & $\begin{array}{c}-0.008^{* * *} \\
(17.66)\end{array}$ \\
\hline $30<$ Age $<=40$ & $\begin{array}{c}0.004^{*} \\
(1.96)\end{array}$ & $\begin{array}{l}0.001 \\
(0.52)\end{array}$ & $\begin{array}{l}0.022 \\
(0.60)\end{array}$ & $\begin{array}{l}0.004 \\
(1.63)\end{array}$ & $\begin{array}{l}-0.000 \\
(0.02)\end{array}$ \\
\hline $40<$ Age $<=50$ & $\begin{array}{c}0.009 * * * \\
(4.44)\end{array}$ & $\begin{array}{c}0.005 * * \\
(2.57)\end{array}$ & $\begin{array}{c}0.065^{*} \\
(1.77)\end{array}$ & $\begin{array}{c}0.007 * * * \\
(3.17)\end{array}$ & $\begin{array}{l}0.018 \\
(1.31)\end{array}$ \\
\hline $50<$ Age $<=60$ & $\begin{array}{c}0.008^{* * *} \\
(3.61)\end{array}$ & $\begin{array}{c}0.004 * * \\
(2.12)\end{array}$ & $\begin{array}{c}0.077 * * \\
(2.07)\end{array}$ & $\begin{array}{c}0.011 * * * \\
(4.68)\end{array}$ & $\begin{array}{c}0.038 * * * \\
(2.61)\end{array}$ \\
\hline Age $>60$ & $\begin{array}{l}-0.000 \\
(0.06)\end{array}$ & $\begin{array}{l}-0.000 \\
(0.24)\end{array}$ & $\begin{array}{l}0.037 \\
(0.89)\end{array}$ & $\begin{array}{l}0.004 \\
(1.56)\end{array}$ & $\begin{array}{c}0.043^{* * *} \\
(2.83)\end{array}$ \\
\hline Log Account Volume in 2001 & $\begin{array}{c}-0.005^{* * *} \\
(14.00)\end{array}$ & $\begin{array}{c}-0.003^{* * *} \\
(11.48)\end{array}$ & $\begin{array}{c}-0.156 * * * \\
(21.85)\end{array}$ & $\begin{array}{c}-0.002^{* * *} \\
(6.00)\end{array}$ & $\begin{array}{c}0.005^{* *} \\
(2.51)\end{array}$ \\
\hline Constant & $\begin{array}{c}0.469 * * * \\
(82.03)\end{array}$ & $\begin{array}{c}0.492 * * * \\
(100.33)\end{array}$ & $\begin{array}{c}1.791^{* * * *} \\
(22.70)\end{array}$ & $\begin{array}{c}0.051^{* * *} \\
(9.12)\end{array}$ & $\begin{array}{c}0.421^{* * *} \\
(10.89)\end{array}$ \\
\hline $\begin{array}{l}\text { Observations } \\
\text { R-squared }\end{array}$ & $\begin{array}{c}28631 \\
0.10\end{array}$ & $\begin{array}{c}28631 \\
0.06\end{array}$ & $\begin{array}{c}28631 \\
0.03\end{array}$ & $\begin{array}{c}28631 \\
0.05\end{array}$ & 28631 \\
\hline
\end{tabular}




\section{Financial Advisors: Extra Slides (beyond the paper)}

\section{Andreas Hackethal}

Goethe University Frankfurt

Michael Haliassos

Goethe University Frankfurt, CEPR, CFS, MEA, NETSPAR

Tullio J appelli

University of Naples, CSEF, CEPR, NETSPAR 
How specific are our results to brokerage accounts? Examining a different data set

- Very large German commercial bank

- Broader customer base than brokerage customers

- Customers with investment accounts

- Panel data over 34 months

- Today: about 3,000 (cross-sectional) observations

- Financial advice:

- All customers have access to bank advisors

- Choose whether they consult one for a specific trade

- Can measure intensity of advisor use

- Dummy (here): Whether they have consulted an advisor for any single trade in the 34-month period

- Can allow for declared risk preferences 


\begin{tabular}{|l|c|}
\hline \multicolumn{1}{|c|}{ Risk Preference } & $\begin{array}{c}\text { Percentage of } \\
\text { sample }\end{array}$ \\
\hline speculator & 13.4 \\
\hline growth & 14.6 \\
\hline balanced & 16.4 \\
\hline conservative & 32.8 \\
\hline low risk & 13.6 \\
\hline safe & 9.2 \\
\hline
\end{tabular}




\section{Some descriptive statistics}

Proportion of accounts that have made use of bank advisor at least once

$30.1 \%$

Average account volume, all accounts

35.403

Mean net monthly rate of return

$0.005 \%$

Mean net annual rate of return

$0.06 \%$

Mean gross monthly rate of return

$0.9 \%$

Mean net annual rate of return

$0.11 \%$ 


\section{Average monthly net returns (\%)}

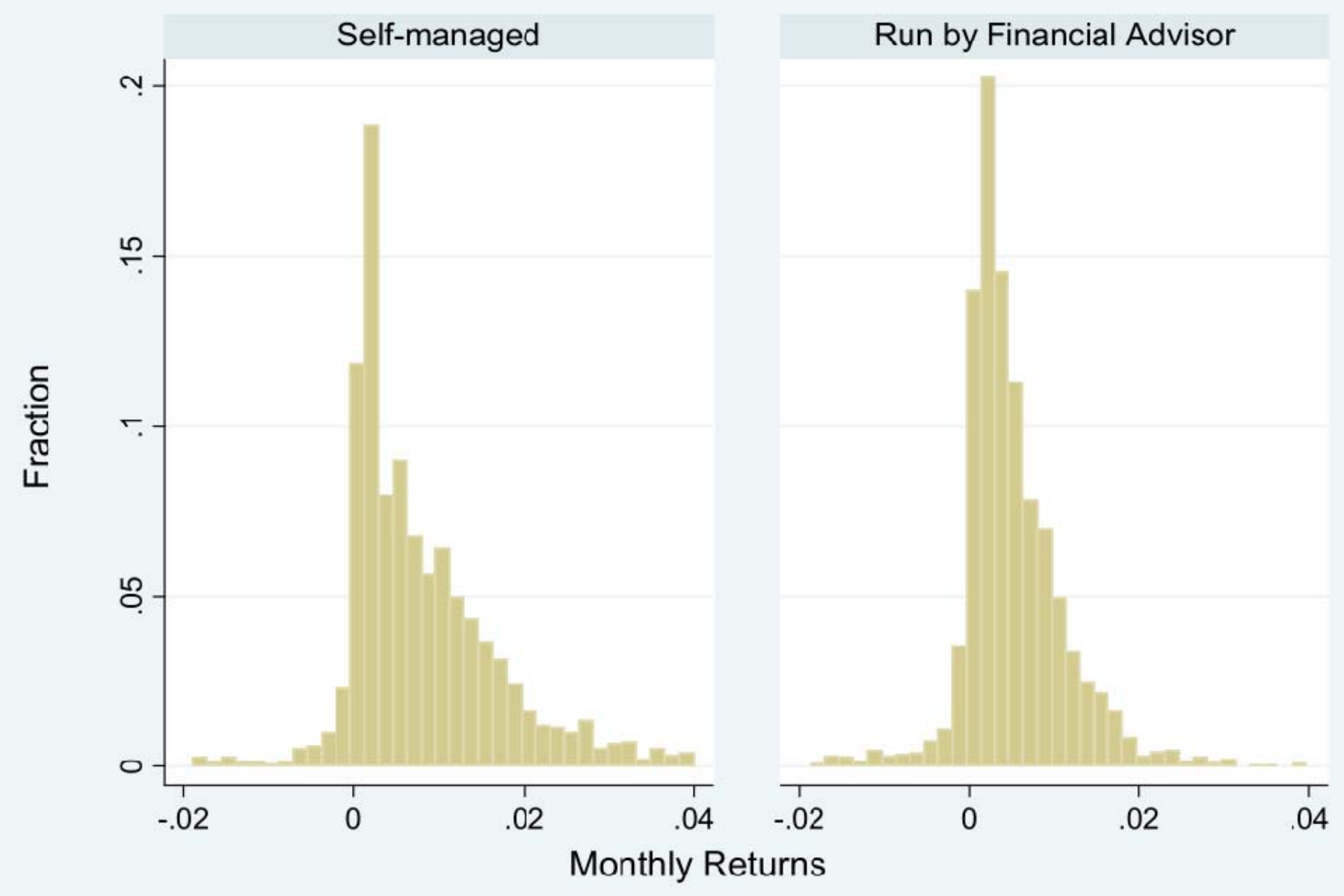




\section{Number of trades per 000 of account volume}

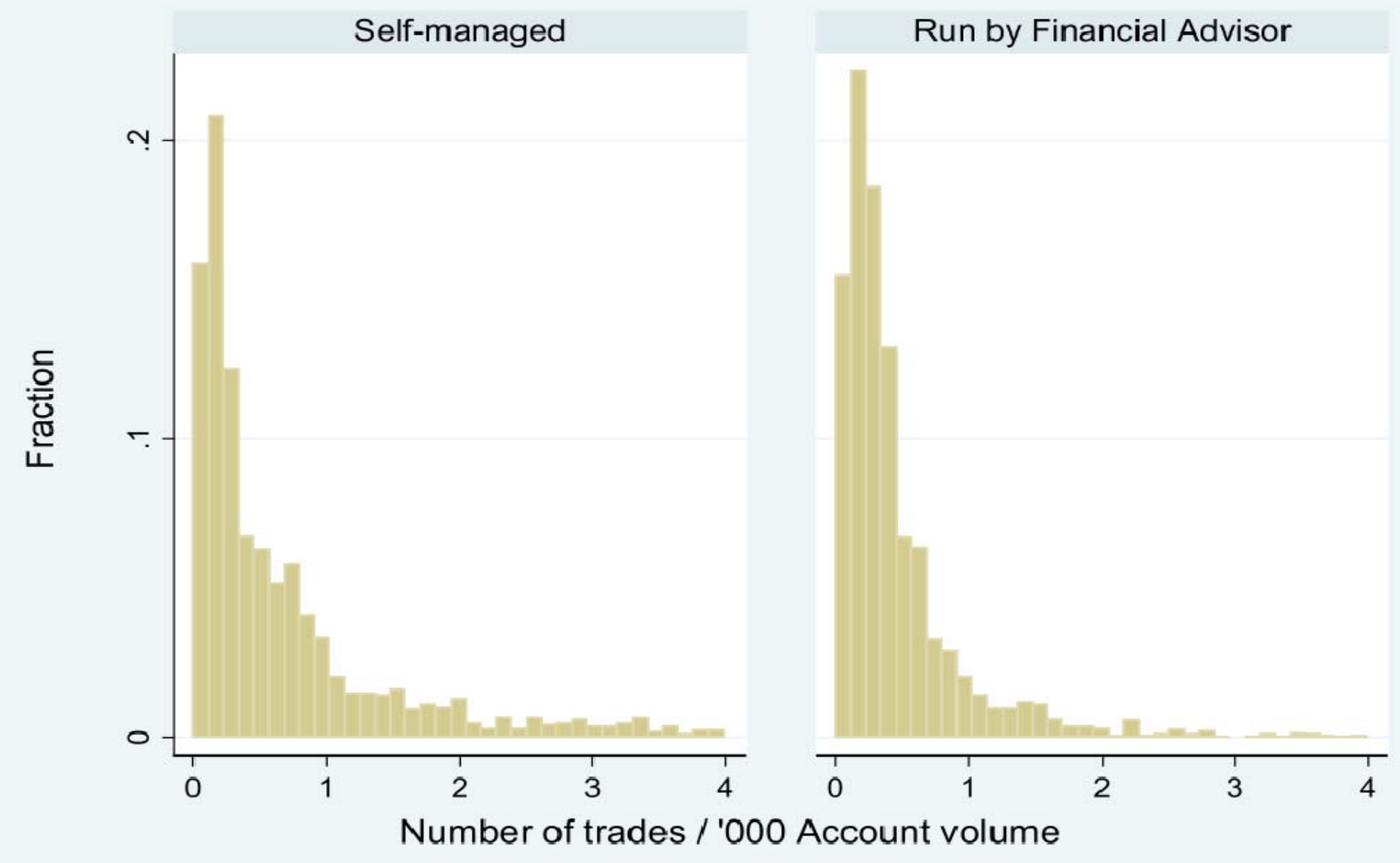




\section{Share of mutual funds in total}

\section{stocks}

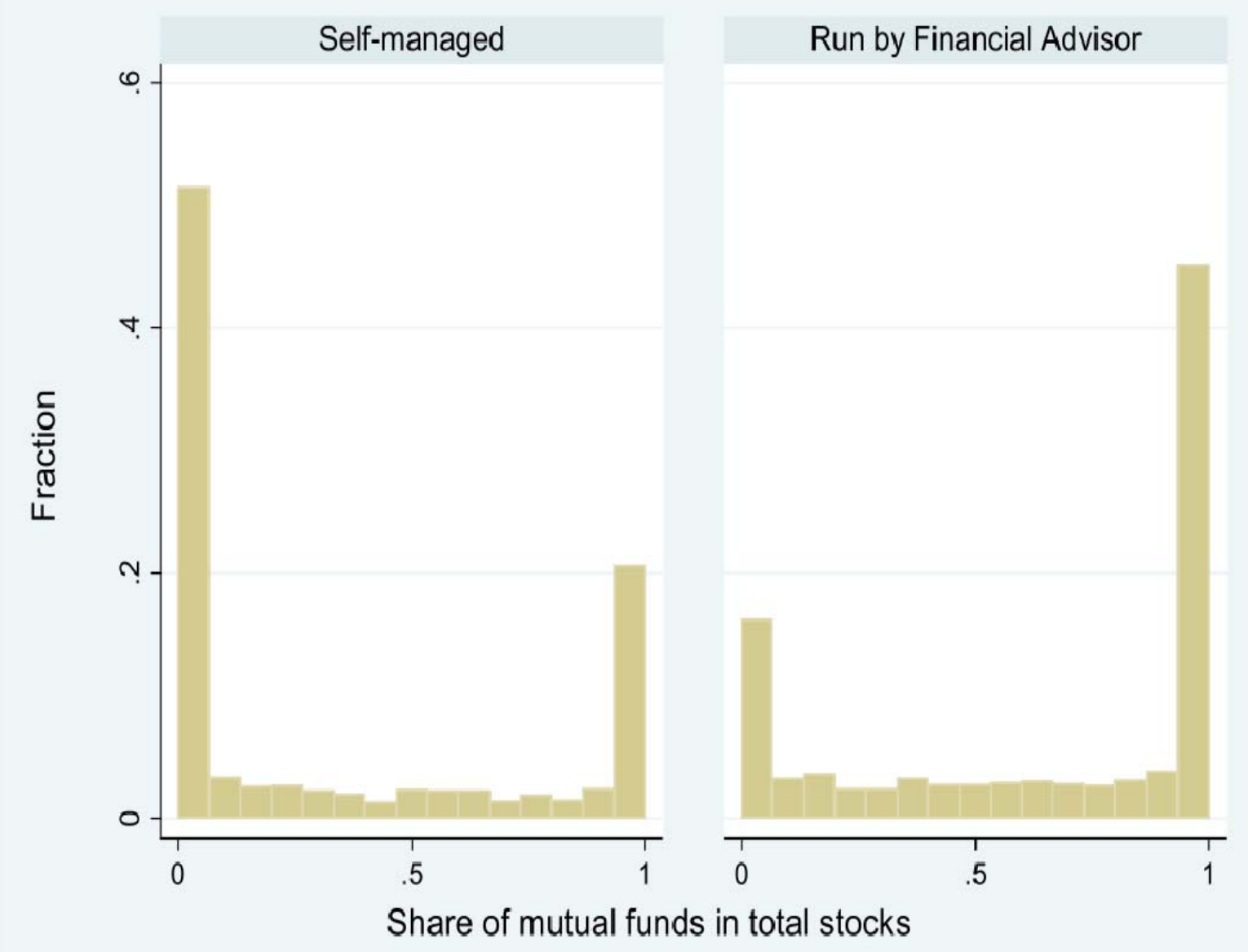


Monthly log net $\quad$ Variance of $\quad$ Share of mutual Number of

\section{OLS Results}

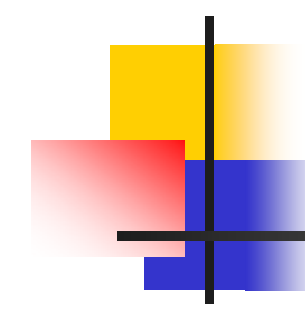

\begin{tabular}{|l|l}
\hline Monthly log net \\
\hline
\end{tabular}

Financial advice

Male

Age

RA: speculator

RA: growth

RA: balanced

RA:

conservative

RA: low risk

White collar

Blue collar

Manager

Retired

Housewife

Student

Constant

\section{returns}

-0.000
$(0.67)$
0.001
$(1.41)$
$-0.000^{* *}$
$(2.54)$

$0.013^{* * *}$

(9.88)

$0.011^{* * *}$

(8.88)

$0.009 * * *$

(7.77)

$0.007^{* * *}$

(6.33)

$0.004 * * *$

(2.87)

0.000

$(0.20)$

$-0.001$

(0.65)

0.001

(0.62)

0.001

(1.19)

$0.002 *$

(1.95)

$-0.003$

(1.57)

0.000

(0.01)

3179 portfolio returns trades / '000 stocks account volume

\begin{tabular}{c}
$-0.013^{*}$ \\
$(1.66)$ \\
-0.010 \\
$(1.48)$ \\
$0.001^{* * *}$ \\
$(3.32)$ \\
$-0.056^{* * *}$ \\
$(3.56)$ \\
$-0.079^{* * *}$ \\
$(5.43)$ \\
$-0.081^{* * *}$ \\
$(5.67)$ \\
$-0.075^{* * *}$ \\
\\
$(5.76)$ \\
$-0.080^{* * *}$ \\
$(5.39)$ \\
$0.024 * *$ \\
$(2.42)$ \\
0.017 \\
$(0.89)$ \\
$0.037^{*}$ \\
$(1.67)$ \\
$-0.024 * *$ \\
$(2.16)$ \\
-0.019 \\
$(1.33)$ \\
0.022 \\
$(1.18)$ \\
$0.070^{* * *}$ \\
$(3.10)$ \\
2961 \\
\hline
\end{tabular}

\begin{tabular}{c}
$0.582^{* * *}$ \\
$(15.50)$ \\
$-0.202^{* * *}$ \\
$(6.03)$ \\
$0.003^{*}$ \\
$(1.86)$ \\
$-0.831^{* * *}$ \\
$(8.32)$ \\
$-0.688^{* * *}$ \\
$(7.07)$ \\
$-0.468 * * *$ \\
$(4.89)$ \\
$-0.495 * * *$ \\
\\
$(5.31)$ \\
-0.086 \\
$(0.75)$ \\
-0.012 \\
$(0.26)$ \\
0.119 \\
$(1.21)$ \\
0.031 \\
$(0.32)$ \\
-0.036 \\
$(0.65)$ \\
-0.054 \\
$(0.79)$ \\
$0.317 * * *$ \\
$(3.57)$ \\
$0.685 * * *$ \\
$(5.26)$ \\
2414 \\
\hline
\end{tabular}

$-0.338 * * *$

(3.57)

0.018

$(0.21)$

$-0.017 * * *$

(4.56)

$0.879 * * *$

(4.61)

$-0.095$

(0.54)

$-0.142$

(0.82)

$-0.164$

(1.04)

$-0.133$

(0.74)

0.022

(0.18)

0.023

(0.09)

$-0.330$

(1.19)

0.069

(0.50)

$-0.164$

(0.93)

$-0.040$

(0.17)

$1.867 * * *$

2414

(6.76)

3179

Observations 


\section{I nstruments}

- average income in the area

- area size

- voter participation

- number of banks per capita 


\section{Regressions}

\begin{tabular}{|c|c|c|c|c|}
\hline & (1) & (2) & (3) & (4) \\
\hline & $\begin{array}{c}\text { Monthly log net } \\
\text { returns }\end{array}$ & $\begin{array}{c}\text { Variance of } \\
\text { portfolio returns }\end{array}$ & $\begin{array}{l}\text { Share of mutual } \\
\text { funds in total } \\
\text { stocks }\end{array}$ & $\begin{array}{c}\text { Number of } \\
\text { trades / '000 } \\
\text { account volume }\end{array}$ \\
\hline Financial advice & $\begin{array}{c}-0.014^{* *} \\
(2.55)\end{array}$ & $\begin{array}{l}0.158^{* *} \\
(2.55)\end{array}$ & $\begin{array}{c}1.132 * * * \\
(4.10)\end{array}$ & $\begin{array}{l}0.020 \\
(0.02)\end{array}$ \\
\hline Male & $\begin{array}{l}-0.000 \\
(0.69)\end{array}$ & $\begin{array}{l}0.007 \\
(1.20)\end{array}$ & $\begin{array}{l}-0.052^{*} \\
(1.85)\end{array}$ & $\begin{array}{l}0.064 \\
(0.64)\end{array}$ \\
\hline Age & $\begin{array}{l}-0.000 \\
(0.05)\end{array}$ & $\begin{array}{l}-0.000 \\
(1.29)\end{array}$ & $\begin{array}{l}-0.001 \\
(1.05)\end{array}$ & $\begin{array}{c}-0.020^{* * *} \\
(4.15)\end{array}$ \\
\hline RA: speculator & $\begin{array}{c}0.008 * * * * \\
(7.08)\end{array}$ & $\begin{array}{l}0.021 \\
(1.53)\end{array}$ & $\begin{array}{l}-0.038 \\
(0.42)\end{array}$ & $\begin{array}{c}0.890 * * * \\
(4.11)\end{array}$ \\
\hline RA: growth & $\begin{array}{c}0.009 * * * \\
(7.70)\end{array}$ & $\begin{array}{l}-0.009 \\
(0.66)\end{array}$ & $\begin{array}{l}0.039 \\
(0.49)\end{array}$ & $\begin{array}{l}-0.099 \\
(0.46)\end{array}$ \\
\hline RA: balanced & $\begin{array}{c}0.008 * * * \\
(5.73)\end{array}$ & $\begin{array}{l}-0.025^{*} \\
(1.78)\end{array}$ & $\begin{array}{l}0.051 \\
(0.65)\end{array}$ & $\begin{array}{l}-0.192 \\
(0.80)\end{array}$ \\
\hline $\begin{array}{l}\text { RA: } \\
\text { conservative }\end{array}$ & $\begin{array}{c}0.005 * * * \\
(3.94)\end{array}$ & $\begin{array}{l}-0.018 \\
(1.28)\end{array}$ & $\begin{array}{l}-0.057 \\
(0.72)\end{array}$ & $\begin{array}{l}-0.207 \\
(0.88)\end{array}$ \\
\hline RA: low risk & $\begin{array}{l}0.001 \\
(1.01)\end{array}$ & $\begin{array}{l}-0.017 \\
(1.18)\end{array}$ & $\begin{array}{l}0.093 \\
(0.98)\end{array}$ & $\begin{array}{l}-0.192 \\
(0.81)\end{array}$ \\
\hline White collar & $\begin{array}{l}0.001 \\
(1.02)\end{array}$ & $\begin{array}{c}0.018 * * \\
(2.16)\end{array}$ & $\begin{array}{l}0.013 \\
(0.34)\end{array}$ & $\begin{array}{l}0.087 \\
(0.63)\end{array}$ \\
\hline Blue collar & $\begin{array}{l}-0.001 \\
(1.01)\end{array}$ & $\begin{array}{l}0.012 \\
(0.76)\end{array}$ & $\begin{array}{l}-0.056 \\
(0.75)\end{array}$ & $\begin{array}{l}-0.003 \\
(0.01)\end{array}$ \\
\hline Manager & $\begin{array}{l}0.001 \\
(0.77)\end{array}$ & $\begin{array}{l}0.029 * \\
(1.68)\end{array}$ & $\begin{array}{l}0.083 \\
(1.15)\end{array}$ & $\begin{array}{l}-0.293 \\
(1.01)\end{array}$ \\
\hline Retired & $\begin{array}{l}0.000 \\
(0.35)\end{array}$ & $\begin{array}{l}0.003 \\
(0.33)\end{array}$ & $\begin{array}{l}0.070 \\
(1.45)\end{array}$ & $\begin{array}{l}0.155 \\
(0.95)\end{array}$ \\
\hline Housewife & $\begin{array}{c}0.002 * * \\
(2.08)\end{array}$ & $\begin{array}{l}-0.002 \\
(0.14)\end{array}$ & $\begin{array}{l}-0.045 \\
(0.86)\end{array}$ & $\begin{array}{l}-0.101 \\
(0.54)\end{array}$ \\
\hline Student & $\begin{array}{l}-0.000 \\
(0.15)\end{array}$ & $\begin{array}{l}-0.016 \\
(1.03)\end{array}$ & $\begin{array}{l}0.050 \\
(0.68)\end{array}$ & $\begin{array}{l}-0.066 \\
(0.26)\end{array}$ \\
\hline Constant & $\begin{array}{c}0.009 * * * \\
(2.68)\end{array}$ & $\begin{array}{l}-0.057 \\
(1.35)\end{array}$ & $\begin{array}{c}-0.383^{*} \\
(1.84)\end{array}$ & $\begin{array}{c}1.742^{* * *} \\
(2.81)\end{array}$ \\
\hline
\end{tabular}




\section{Concluding Remarks}

- Matching:

- Not for granted that financial advisors are matched with uninformed novices and attract low-quality investors

- Regulation

- Reliance on advisors to assist those likely to make mistakes

- Contribution of financial advisors:

- Even if advisors add value, they end up collecting more in fees and commissions than what they add

- Seems robust across IFAs and BFAs and across brokerage and bank clients

- Interpretation:

- Why do even high-quality investors at the brokerage pay this?

- Pay for a service because they have no time (like babysitting)?

- Think in relative terms?

- They get the DAX index return, which is better than others get

- Half pay less relative to what they were paying to the bank

- Do IFAs turn non-participants to participants?

- Policy implication for retirement financing:

- Financial advice may not be a reliable substitute for financial literacy

- More promising: simpler products and default options

- Policy implication for regulation and transparency:

- MIFID requires financial institutions to elicit and rate investors' financial abilities through simple questionnaires. Is this the end of the story?

- If many of them offer a luxury service to wealthy investors, how should we think about regulation? 